\title{
Human Schistosome Infection and Allergic Sensitisation
}

\author{
Nadine Rujeni, David W. Taylor, and Francisca Mutapi \\ Institute of Immunology and Infection Research, Centre for Immunity, Infection, and Evolution, School of Biological Sciences, \\ University of Edinburgh, Ashworth Laboratories, King's Buildings, West Mains Rd, Edinburgh EH9 3JT, UK
}

Correspondence should be addressed to Francisca Mutapi, f.mutapi@ed.ac.uk

Received 14 May 2012; Accepted 28 June 2012

Academic Editor: Maria Ilma Araujo

Copyright ( 2012 Nadine Rujeni et al. This is an open access article distributed under the Creative Commons Attribution License, which permits unrestricted use, distribution, and reproduction in any medium, provided the original work is properly cited.

\begin{abstract}
Several field studies have reported an inverse relationship between the prevalence of helminth infections and that of allergic sensitisation/atopy. Recent studies show that immune responses induced by helminth parasites are, to an extent, comparable to allergic sensitisation. However, helminth products induce regulatory responses capable of inhibiting not only antiparasite immune responses, but also allergic sensitisation. The relative effects of this immunomodulation on the development of protective schistosome-specific responses in humans has yet to be demonstrated at population level, and the clinical significance of immunomodulation of allergic disease is still controversial. Nonetheless, similarities in immune responses against helminths and allergens pose interesting mechanistic and evolutionary questions. This paper examines the epidemiology, biology and immunology of allergic sensitisation/atopy, and schistosome infection in human populations.
\end{abstract}

\section{Introduction}

The major human helminth parasites belong to two phyla, the nematodes (or roundworms) which include intestinal soil transmitted helminths (STH) and filarial worms (which cause lymphatic filariasis and onchocerciasis), and the platyhelminths (or flatworms) which include the flukes (or trematodes, including schistosomes) and the tapeworms (or cestodes). Although common in most parts of the world sixty years ago [1], these parasites are currently mainly prevalent in sub-Saharan Africa, Asia, and South America [2-4], where they are responsible for considerable disabilities including blindness and elephantiasis (filarial worms). Furthermore, helminth infections are responsible for morbidities that include anaemia, stunted growth, poor cognitive development, and malnutrition [5-7], hence exert a negative socioeconomic impact in some of the poorest communities in the world.

Immune-mediated diseases including auto-immune diseases (such as type 1 diabetes, inflammatory bowel diseases, and rheumatoid arthritis) and allergic diseases (such as asthma, allergic rhinitis, and atopic eczema) are reported to be more prevalent in developed countries and in urban areas of developing countries $[8,9]$. But studies from Africa are demonstrating that allergic diseases are common, if not acknowledged, clinical problems in this region [10]. Immune disorders have been responsible for increased mortality and morbidity worldwide [11-13] and they negatively impact on economic growth due to their elevated cost of their treatment $[14,15]$. There is also mounting evidence that allergic disorders, especially allergic rhinitis, are associated with attention deficit disorder and hyperactivity in children $[16,17]$.

Increasing rates of childhood allergies have long been a puzzle to epidemiologists $[18,19]$. Thus, studying cohorts of children born in 1946, 1958, and 1970, concluded that a "new environmental agent," contained in breast milk and possibly infants' food was responsible for the increase in eczema. Emmanuel, reviewing medical literature published from 1820 to 1900 , suggested that the hay fever "epidemic" was associated with the rapid industrial growth of the 19th century since this disorder was rarely described prior that period [19]. It was Strachan who in 1989, observing that the rate of hay fever and eczema was consistently negatively associated with family size and birth position in households, hypothesized that reduced exposure to childhood infections due to increased hygiene was responsible for the allergy epidemics. This hypothesis, currently referred to as 
TABLE 1: Heterogeneity in studies investigating the effect of helminth infection on atopy.

\begin{tabular}{|c|c|c|c|}
\hline Parasite spp, References & Atopy outcome & Association & Population age \\
\hline \multicolumn{4}{|l|}{ Ascaris lumbrocoides } \\
\hline$[37]^{1}$ & Wheeze, SPT & Negative & $1-4$ years \\
\hline$[38]^{2}$ & IgE, PK & Negative & $5-15$ years \\
\hline$[39]^{1}$ & SPT, airway responsiveness & Positive & $8-18$ years \\
\hline$[40]^{2}$ & Allergen-induced Th2 cytokines & None & $7-13$ years \\
\hline$[41]^{2}$ & SPT, wheeze & None & 9 years mean age \\
\hline \multirow[t]{2}{*}[42]{$^{2}$} & SPT & Negative & $6-17$ years \\
\hline & Wheeze, eczema, EIB & None & \\
\hline \multicolumn{4}{|l|}{ Trichuris trichiura } \\
\hline$[38]^{2}$ & IgE, PK & Negative & $5-15$ years \\
\hline$[37]^{1}$ & Wheeze, SPT & None & $1-4$ years \\
\hline$[43]^{\#}$ & SPT & Negative & $2-8$ years \\
\hline \multicolumn{4}{|l|}{ Hookworm } \\
\hline$[37]^{1}$ & Wheeze, SPT & None & $1-4$ years \\
\hline \multirow[t]{2}{*}[42]{$^{2}$} & SPT & Negative & $6-17$ years \\
\hline & wheeze, eczema, EIB & None & \\
\hline \multicolumn{4}{|l|}{ Schistosoma mansoni } \\
\hline$[44]^{1}$ & SPT, IgE & Negative & $18 \pm 9.7$ years \\
\hline$[45]^{\#}$ & SPT, asthma symptoms & Negative & 15 years mean age \\
\hline \multicolumn{4}{|l|}{ Schistosoma haematobium } \\
\hline$[46]^{1}$ & SPT & Negative & 5-14 years \\
\hline
\end{tabular}

Cross-sectional $^{1}$ and treatment followup ${ }^{2}$ studies are reported here.

${ }^{\#}$ Longitudinal approach but treatment intervention was not the primary objective of the study. SPT: skin prick test; PK: Prausnitz-Kustner passive transfer test, EIB: exercise-induced bronchoconstriction.

the "hygiene hypothesis," was subsequently supported by some epidemiological studies [20, 21] but contradicted by others $[22,23]$ (see summary in Table 1 ). In a retrospective case control study on Italian military cadets, Matricardi and colleagues were able to show that cumulative exposures to foodborne and oral-faecal infections, but not infections transmitted via other routes, were associated with a reduced risk of being atopic [24]. They suggested that the mode of transmission of the pathogen was a determining factor in subsequent protection (or lack of protection) against atopy and asthma, hence explaining inconsistencies in previous studies.

\section{Global Burden of Schistosomiasis and Atopy}

2.1. Schistosomiasis. Schistosomiasis accounts for up to 70 million DALYs annually [6], with an estimated 15,000 deaths [4], and children carry the heaviest burden of infection [47]. With these figures, schistosomiasis is classified second only to malaria in terms of human morbidity and mortality due to parasitic diseases [48]. Schistosomiasis is caused by infection with blood-dwelling trematodes of the genus Schistosoma, of which S. haematobium, S. mansoni, and S. japonicum are the main human schistosomes [49]. It is typically prevalent in rural areas where natural streams, ponds, rivers, and lakes harbouring the infected intermediate host snails, are the main sources of water for domestic or occupational purposes such as washing and fishing. School children usually become infected during swimming or collecting water, while younger children and infants become infected when accompanying adults (washing clothes or collecting water) or by being bathed in these water sources [50].

2.2. Atopy. Rising rates of atopic diseases have been reported in developed countries since the end of World War II [18] and currently constitute a major public health issue [51]. Demographic data in the US have shown an average increase in childhood asthma prevalence of 4.3\% per year from 1980 to 1996 , with associated deaths and hospitalisation increasing by $3.4 \%$ and $1.4 \%$, respectively [52]. In the United Kingdom, according to the British Allergy Foundation, 1 in 3 people suffer from allergy at some time in their lives. This report indicates that $58 \%$ of allergic sensitisations are triggered by house dust mites (HDM), a known risk factor for developing asthma and allergic rhinitis [53, 54]. Increasing prevalence of asthma in adults over a period of 10 years and doubling in school children over 20 years have been reported in Australia [55]. A recent study involving 12 European countries and 19 centres reported incidences of asthma between 5 and $17 \%$ (average 8\%), while allergic rhinitis varies between 23 and $44 \%$, with an average of $30 \%$ [56].

In less affluent countries, comparable rates of atopic diseases are generally reported in urban and suburban areas. Thus, a prevalence of asthma of $9 \%$ was reported in urban 
areas of Rwanda [57] while the International Study of Asthma and Allergies in childhood (ISAAC) reported an overall prevalence of $10.9 \%$ across 22 centres in Africa [58]. Reported incidences of allergic rhinitis range from $14 \%$ to $54 \%$ in urban and suburban areas across African countries (reviewed by [59]). Importantly, according to the ISAAC phase three, although the prevalence was generally lower, there were more severe symptoms of rhinoconjnnctivitis reported in urban centres of developing countries compared to those reported in developed countries [8]. However, studies from Africa suggest that allergic conditions may be underdiagnosed in Africa due to "inappropriate" diagnostic tests and these studies call for component-resolved allergy testing in Africa [60]. Indeed a recent study in Zimbabwe showed that schistosome-infection resulted in impaired diagnosis of cat allergy [61].

\section{Atopy and Schistosome Life-Cycle Stages}

In schistosome infection, the human immune system is exposed to schistosome larvae (cercariae and schistosomula), adult worm, and egg antigens. Animal studies as well as in vitro studies have demonstrated immunological changes and regulatory mechanisms associated with these different life-cycle stages. The surface of cercariae (enriched in carbohydrates [62]) and the newly transformed schistosomula activate the complement cascade $[63,64]$ and eliciting proinflammatory responses $[65,66]$. An excessive immunological reaction to skin stage cercarial antigens results in cercarial dermatitis or swimmer's itch [67], an allergic condition also occurring in contact with nonhuman schistosomes that is prevalent in developed countries [68-70]. This inflammatory reaction is rarely reported in populations in which schistosomiasis is endemic, possibly due to regulatory responses resulting from multiple exposures as has been demonstrated in mice [71]. Such regulatory responses may be induced by skin-stage schistosomula-derived molecules such as prostaglandin $\mathrm{E}_{2}\left(\mathrm{PGE}_{2}\right)$ which upregulates IL-10 production during skin penetration by the parasite [72] The $\mathrm{PGE}_{2}$ is also secreted by the lung-stage schistosomula during migration through the capillary beds of the lungs, and this is thought to diminish eosinophil infiltrates around the parasites (and thus inflammation [73]). In addition, these parasites are capable of inhibiting the expression of endothelial adhesion molecules such as E-selectin and VCAM-1, limiting leucocyte recruitment in the lungs [74]. These anti-inflammatory mechanisms in the lungs have been suggested as potential explanations for reduced severity of asthma symptoms in schistosome-infected asthmatic patients [45], although there are no mechanistic studies from human populations to support this.

Schistosome eggs are major Th2 triggers as demonstrated in murine studies $[75,76]$, and they induce formation of fibrotic lesions or granulomas [77-79]. Indeed, an S. mansoni egg-secreted glycoprotein, omega- 1 , has recently been identified that conditions dendritic cells for Th2 polarisation [25]. However, egg secretions are capable of inhibiting the specific binding of chemokines such as CXCL8 (IL-8) and CCL3 $(\mathrm{MIP}-1 \alpha)$, therefore blocking chemokine-elicited migration of neutrophils and macrophages respectively during granuloma formation [80].

Schistosome adult worm antigens also induce Th2 responses and IgE in mice [81], baboons [82], and humans [83]. However, this parasite life stage elicits high levels of modulatory responses capable of inhibiting antiparasite [84] as well as allergic reactions [85]. The latter study demonstrated that worm infection induces IL-10, producing $\mathrm{B}$ cells that could protect mice against anaphylaxis. They later demonstrated that egg-laying worms exacerbate while single sex worms (precluding egg production) inhibit airway hyperresponsiveness [86].

Together, these studies show that the different parasite life-cycle stages are associated with different mechanisms of regulation and inflammation. Although concurrent exposure to all or most antigens is likely in endemic areas, and despite the fact that they may induce cross-reactive immune responses [87], the different parasite life-cycle stages may differentially affect atopic responses.

\section{Epidemiology}

4.1. Schistosomiasis. The epidemiological patterns of schistosomiasis differ from those of atopy, mainly because of their aetiology. Indeed, while schistosome infection is acquired as a result of exposure to parasites, atopy is a genetic predisposition (although the clinical manifestations are influenced by environmental factors). In schistosome endemic areas, infection levels follow a convex shape with host age, where infection intensity rises to peak in childhood-adolescence and decline in adulthood [88]. This peak was initially interpreted as arising from different water contact levels between age groups [89]. However, longitudinal studies showed that with the same exposure rate, "resistant" individuals were older than "susceptible" individuals [90-92], suggesting an age-dependent acquired resistance to reinfection. In addition, in communities of different parasite transmission, infection intensity peaks at a younger age in areas of high transmission compared to low-transmission areas [88, 9395], a phenomenon referred to as a "peak shift." This phenomenon has been interpreted as reflecting different rates of development of acquired resistance to infection during schistosome infection as has been reported for Plasmodium infections (which cause malaria) [96, 97]. This interpretation is supported by age-related changes in immune responses, with the peak of antibodies and cytokine associated with protection coinciding with the decline in infection levels have been reported in S. haematobium endemic areas [83, 98, 99]. More recently, Black and colleagues observed that the rate of acquisition of antischistosome protective responses by adults occupationally exposed to $S$. mansoni, following treatment, is dependent on their history of exposure, being faster in those with a longer history [100]. This study, consistent with earlier studies [101, 102], demonstrated that resistance to schistosome infection/reinfection is acquired independent of age related physiological changes [103].

4.2. Atopic Diseases. Atopy is the genetic predisposition to become excessively sensitised and produce high levels of 
IgE [104]. However, atopic diseases result from a genetic predisposition in combination with environmental stimuli such as allergens, smoke, diet, and/or infectious agents $[105,106]$. The epidemiology of atopic diseases is complex as some diseases may become more prominent with age while others diminish or disappear [107]. The earliest phases of atopic diseases usually manifest during the first five years of life and the severity (and prevalence) of clinical symptoms seem to increase in late childhood/adolescence and plateau throughout adulthood [108-110] or decline for some conditions $[111,112]$.

It has been suggested that a natural history of allergy manifestations in atopic individuals involves progression from atopic eczema (below one year of age) to asthma or allergic rhinitis (late childhood/adolescence), a phenomenon referred to as the "atopic/allergic march" [112]. However, this is not always consistent as some children may develop atopic dermatitis long after the onset of asthma [113], while some atopic individuals may only develop one of these conditions throughout life. Longitudinal studies indicate that atopy in infancy predicts the occurrence and severity of asthma [114] and bronchial hyperresponsiveness [115] in later life. Total and allergen-specific IgE levels also seem to increase throughout childhood in allergic individuals [116]. However, a number of events occurring in the first few years of life and in utero are likely to influence the onset and persistence of disease. Thus, Klinnert and colleagues have shown that respiratory infections during the first year of life and parenting difficulties (e.g., postnatal maternal depression) were independent predictors of the onset of asthma during early ( 3 years) and late ( $6-8$ years) childhood in children at risk $[114,117]$.

Microbial exposures and diet of pregnant mothers may also alter early gene expression in neonates, influencing the onset of allergy in childhood (see $[106,118]$ ). Consistent with this hypothesis is the finding that maternal exposure to farm milk and farm animals during pregnancy was associated with demethylation within the FOXP3 (Treg transcription factor) locus in cord blood and subsequent elevated levels of regulatory $\mathrm{T}$ cells (Tregs) (and their suppressive activity) in offspring [119]. Murine studies have also shown that, when exposed to a methyl rich diet during pregnancy (as may be the case for folate supplementation in humans), foetal DNA may undergo changes in methylation that results in decreased gene transcription activity, leading to subsequent enhanced development and severity of allergic diseases [120]. The study also showed that this diet-associated allergic phenotype was transgenerationally inheritable (persistence of high levels of IgE and eosinophilia into the F2 generation).

\section{Effector Responses in Atopy and Schistosome Infection}

5.1. Immunoglobulin E. Identified in the 1960 s as a "carrier of reaginic activity" $[121,122], \operatorname{IgE}$ is well known as a central player in atopic diseases and anaphylactic reactions. This antibody is part of a protein network involving its 3 receptors, namely, the FceRI, the CD23 (or FceRII) and galectin-3 [32], all of which can be found in soluble forms
$[123,124]$. The FceRI (also termed high-affinity receptor) is mainly expressed on mast cells and basophils but also on epidermal Langerhans cells [125] and eosinophils [126, 127]. Cross-linking of these high-affinity receptors by IgE induces activation of mast cells and basophils and their degranulation. The galectin-3 receptor is expressed on neutrophils and on trophoblast cells in placentas [128], where it is thought to facilitate IgE transport [129]. The CD23 receptor facilitates the transport of IgE-antigen complexes but is also involved in the regulation of IgE synthesis [32]. Highly conserved in mammalian lineages [130], IgE is thought to have evolved as a first line of defence against helminth parasites.

IgE antibodies are naturally strongly regulated and have the lowest concentrations of all antibodies in serum of healthy nonatopic individuals [32]. Mechanisms of regulation of IgE include its short half-life in serum $(12 \mathrm{~h}$ for murine monoclonal antibodies [131]), the poor processing of mRNA for the membrane $\varepsilon$ heavy chain [132], and the negative feedback regulation by the CD23 [133]. The latter has been a subject of investigations in terms of therapeutic application in atopic diseases but also in autoimmune diseases [134] and chronic lymphocytic leukaemia [135].

5.2. CD23. CD23 is the low-affinity receptor for $\operatorname{IgE}$ and differs from the high-affinity FceRI receptor in structure and function. Thus, while cross-linking of the latter results in degranulation of mast cells and release of mediators, engagement of membrane-bound CD23 suppresses the production of IgE by B lymphocytes [33]. CD23 has long been proposed as a natural regulator for IgE synthesis [133] although elevated levels of CD23 + B cells have been reported in atopic patients [136]. As initially suggested by Aubry and colleagues [137], CD23 not only binds IgE but also CD21, a cell-surface protein expressed on T-cell, B-cell, and follicular dendritic cells, classically identified as a receptor for complement proteins [138] or Epstein-Barr virus [137]. The interaction between CD23, IgE, and CD21 may lead to either negative or positive regulation of IgE synthesis (reviewed in [34-36]). The binding of IgE stabilises membrane-bound CD23 and inhibits IgE synthesis from activated B cells, while in the absence of IgE binding, CD23 is cleaved by ADAM10 (a disintegrin and metalloprotease protein 10), and this destabilisation enhances IgE synthesis [32]. Soluble CD23 (sCD23) fragments resulting from the cleavage can bind to IgE with different affinities and outcomes for IgE synthesis depending on their oligomerization state. Trimers bind IgE with high affinity and enhance IgE synthesis by their ability to also bind the CD21 receptor while monomers bind with low affinity but do not bind CD21 and hence inhibit IgE synthesis $[36,139]$.

5.3. Immunoglobulin 4. Serum IgG4 antibodies, the least abundant among human IgG subclasses, have long been associated with IgE-mediated diseases [140-142]. However, rather than the cause of disease, these antibodies seem to be involved in the regulation of IgE-induced anaphylactic reactions [143]. IgG4 may interfere with antigen recognition by IgE due to their similar antigenic specificity [144], although different epitope-binding [145]. In a process that 
involves exchange of fab molecules, IgG4 are structurally hetero-bivalent (each heavy chain and light chain recognising a different epitope within a single IgG4 molecule) and often function as monovalent $[141,146]$, to bring about antiinflammatory effects [147]. The interaction between IgG4 and a given antigen results in small and non-pathological immune complexes (since these antibodies cannot crosslink antigens) [146]. Furthermore, in contrast to other IgG subclasses, IgG4 cannot fix complement but inhibits complement activation by IgG1 [148]. IgG4 antibodies, in allergy or helminth infection, are secreted in response to high antigen loads [141, 149, 150] but levels of the antibodies are differentially regulated by the same cytokines [151] as those regulating IgE, suggesting an important homeostatic mechanism for controlling IgE-mediated responses.

\section{Control of Effector Responses in Atopy and Schistosome Infection}

In addition to the cross-regulation between Th1 and Th2 [152] (and potentially other T cell subsets), there is growing evidence that Th2 cells interact with a complex network of other T cell subsets as well as B cells and antibodies, naturally or during disease (atopic or infectious). Thus, it has emerged that Tregs play an important role in the tolerance of ubiquitous antigens and that alterations in Treg function $[153,154]$ and/or the fine balance between Tregs and Th2 cells $[155,156]$ determines the clinical manifestation of atopy. Indeed, in healthy (nonatopic) individuals $\mathrm{T}$ cell polarization occurs in contact with environmental allergens but higher levels of Tregs dampen the effect of Th2 cells, leading to peripheral tolerance [156]. Tregs modulate the activity of Th2 (and Th1) cells via several mechanisms including the secretion of anti-inflammatory cytokines such as IL-10 and TGF- $\beta[155,157]$. As the description and role of other recently identified T-helper cells is clarified (e.g., Th17 cells shown to be important in nonatopic asthma) regulation of Th2 mediated responses will also become clearer [158]. The role of cells such as the T-helper cells recently shown to produce both IL-17 and Th2 cytokines (IL-4, IL-5, IL9, and IL-13) [159] in pathogenesis is currently under intense investigation. Our own group has recently described a role for Th17 responses in human schistosome-acquired immunity (submitted).

IL-10 producing B cells (Bregs) are also involved in the recruitment of Tregs, hence contributing to the regulation of Th2 responses as demonstrated in murine models of helminth infection (see [31]). IL-10 can inhibit effector functions of mast cells and eosinophils, and regulate the growth of several cells including B cells, NK cells, mast cells, and dendritic cells. Furthermore, IL-10 modulates IgE : IgG4 ratios [154] possibly by indirectly inducing the antibody switch to IgG4 in the B-cell progeny while preventing $\operatorname{IgE}$ production [160].

IgG4 may control IgE-mediated histamine release as has been demonstrated in filarial infection [143]. Furthermore, it has recently been shown that the binding patterns of IgG4 antibodies correspond to natural recovery from childhood
IgE-mediated milk allergy [161], suggesting their potential protective role in atopic diseases, although this is still controversial [141]. In addition, early observations that IgG4 antibodies were highly elevated in sera of patients receiving allergen immunotherapy [162] have prompted the use of IgE : IgG4 ratio as a marker for successful immunotherapy $[142,163,164]$. In helminth infections, high IgG4 : IgE ratio has been associated with reduced pathology while favouring a heavy worm load $[150,165,166]$. Interestingly, IgG4 may be one of the "regulatory antibodies" resulting from IgG syalilation involved in the control of immune disorders [167, 168].

\section{Immune Responses in Atopy}

The human immune system must distinguish between a dangerous pathogen and ubiquitous environmental allergens and has evolved to mount appropriate defensive responses to the first while tolerating (or ignoring) the latter. However, a certain proportion of individuals fail to tolerate environmental allergens and develop allergic diseases such as asthma, atopic dermatitis and allergic rhinitis. These result from excessive sensitisation to ordinary exposures to allergens [104]. IgE antibodies are critical effector molecules in the pathogenesis of these diseases [169]. Mast cells and basophils are coated with specific IgE antibodies and this results in immediate hypersensitivity (release of mediators) and/or late-phase inflammatory reaction (cytokine secretion and recruitment of leucocytes).

In atopic individuals, allergen products (e.g., cysteine proteases) activate epithelial cells, which produce thymic stromal lymphopoietin (TSLP), IL-25, and IL-33 which in turn initiate Th2 polarisation with increased production of IL-4, IL-5, IL-9, and IL-13 cytokines [170, 171]. Th2 cytokines are involved in the class-switching to $\operatorname{IgE}$ as well as the development and recruitment of basophils, mast cells, and eosinophils (see Figure 1(c)). IgE binds to the high-affinity FceRI receptor on mast cells, basophils, and eosinophils which (upon exposure to allergens) results in their activation and degranulation (via cross-linking of allergens), with the release of preformed mediators such as histamine, cysteinyl leukotrienes, and prostaglandin $\mathrm{D}_{2}$ $[154,172]$.

A complex interplay between innate and adaptive immune responses underlies the heterogeneous characteristics of atopic diseases. Thus, recruitment of eosinophils into the lungs of asthmatics may be promoted not just by Th2 (IL-5) alone but in conjunction with natural killer T cells (NKT) as well as CD8+ T cells (see [173]). In addition, IL17-producing T cells (Th17 [174]) may be involved in the severity of asthma [175]. These promote the recruitment and activation of neutrophils and lead to corticosteroidsresistant asthma [175]. IL-9-producing T-cell subset (Th9), which probably derive from Th2 cells under the influence of TGF $\beta 1$ [176], may also be involved in the production of IgE and mast cell recruitment in the lungs [173]. In allergic rhinitis, mast cells accumulate in the epithelium of the nasal mucosa where they secrete inflammatory cytokines (IL-6, IL8 , and TNF $\alpha$ ) in addition to Th2 cytokines [177]. 


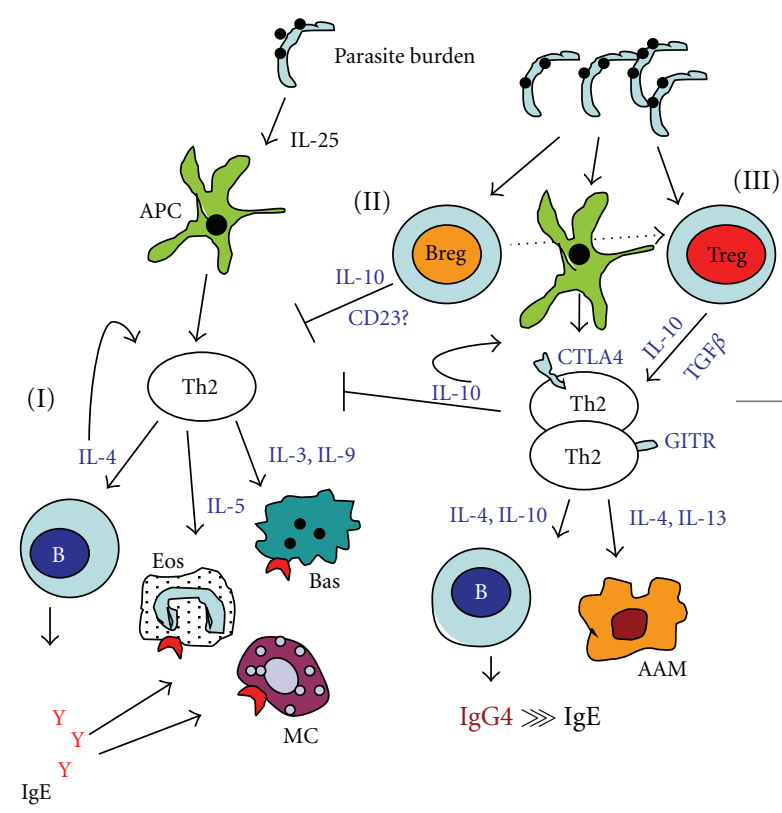

(a) Primary infection

(b) Secondary/chronic infection

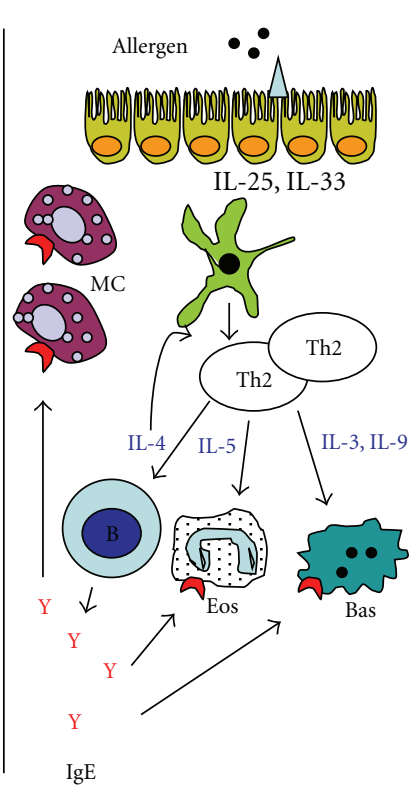

(c) Atopic inflammation

FIgure 1: Possible regulatory mechanisms in helminth infections. Primary response (a) to parasite antigens involves Th2 polarization, IgE production, and eosinophil, mast cell, and basophil activation (I), mechanisms similar to those observed in allergic sensitisation (c). This Th2-response may be induced by parasite-secreted antigens such as the Omega-1 secreted by S. mansoni eggs [25]. However, with increasing parasite load or chronic infection (b), regulatory B cells are activated which suppress Th2 responses (II) via IL-10 secretion or CD23 expression [26], and/or contribute to the recruitment of Tregs [27]. Tregs (III), which may also be induced and expanded by parasite antigens $[28,29]$, either induce anergic Th2 cells (expressing GITR and CTLA4) unable to progress through to effector cells, or modify downstream effector functions such as B cell switch to IgG4 and/or alternative activation of macrophages, resulting in immunological tolerance (reviewed by [30]). This immunosuppression is induced in the context of helminth infection, but may also expand to allergeninduced inflammation (gray line), hence suppressing allergy. DC: dendritic cell; B: B cell, Eos: eosinophil; Bas: basophil; MC: mast cell; GITR: glucocorticoid-induced TNF $\alpha$-related protein; CTLA4: cytotoxic T lymphocyte antigen 4; AAM: alternatively activated macrophage; Breg: regulatory B cell; Treg: regulatory T cell. The question mark (?) denotes lack of strong evidence. Figure adapted from [30, 31] and collated information from the cited references.

\section{Immune Responses during Schistosome Infection}

Acquired immunity to schistosome infection was first proposed by Fisher in the 1930s when analysing data from animal studies as well as those from hospital-diagnosed S. haematobium infected people [88]. Subsequently, the susceptibility of schistosome larvae to immune attack was demonstrated by in vitro studies showing that sera from $S$. mansoni infected individuals could damage schistosomula in the presence of normal human peripheral blood leucocytes [178]. This "antibody-dependent" killing was subsequently shown to be eosinophil mediated [178, 179], and studies on monoclonal antibodies led to the identification of IgE antibodies with the highest cytotoxicity for the schistosomula [180-182]. Field studies were conducted to identify antibody responses predictive of resistance to reinfection following chemotherapy. Hagan et al. [83] demonstrated in a multivariate logistic regression that reinfection with $S$. haematobium was less likely in individuals producing high IgE levels against the worm antigens and more likely in those producing high levels of IgG4 against the worm or egg antigens. The role of IgE in resistance was also demonstrated by Rihet et al.
[183], who identified specific antigens (120-165 KDa and $85 \mathrm{KDa}$ ) to which IgE reacted (on immunoblots) and showed that these antibodies, in contrast to IgM and IgG, were significantly higher in the sera of the most resistant individuals. This study showed that some of the immunogenic antigens were readily accessible to IgE on living $S$. mansoni larvae as they were located on the outer membrane. However, Dunne and colleagues, working on S. mansoni as well, showed that $\operatorname{IgE}$ (produced following treatment) against adult worm antigens, particularly a $22 \mathrm{kDa}$ tegumental antigen (Sm22), but not against any other life-cycle stages, were associated with resistance to reinfection following treatment [184]. Both antiadult worm and anti-schistosomula tegument IgE antibodies were associated with resistance to $S$. mansoni reinfection in another study in Brazil [185] while antiegg IgE antibodies also could confer protection against $S$. japonicum reinfection [186].

Collectively, these studies and several others [187-190] have led to the conclusion that resistance to schistosome infection/reinfection is dependent on IgE antibodies. However, data on other antibody isotypes have been reported which correlated with resistance to infection/reinfection. For example, IgG3 against the recombinant antigen Sh13 has 
been associated with resistance to $S$. haematobium infection [191], while antiworm and cercariae IgM were significantly higher in individuals more resistant to reinfection with $S$. mansoni [185]. Furthermore, a decline in IgA together with an increase in IgG1 were associated with resistance acquired with host age as well as following treatment in S. haematobium endemic area [192]. IgA against Sm28GST antigen has also been associated with reduced $S$. mansoni fecundity and increased host resistance to reinfection [193]. More recently, antiworm IgE antibodies, as well as eosinophilia and the low affinity receptor for IgE (the CD23) have been shown to correlate with resistance in individuals undergoing multiple rounds of treatment $[100,194]$, again suggesting that IgE may be directly involved in parasite killing via antibody-dependent cellular cytotoxicity (ADCC) in vivo. However, since schistosomula are more susceptible to ADCC, it is possible that adult-worm-specific antibody responses may rather target the incoming larvae, a process termed "concomitant immunity" (as predicted by Fisher [88]) and well demonstrated in rhesus monkeys [195].

As initially demonstrated by in vitro studies [196-198], ADCC is dependent on Th2 cytokines, and these have been involved in resistance to schistosome infection. Thus, higher ratios of IL-4/IFN- $\gamma$ and IL-5/IFN- $\gamma$ were produced by specific T-cell clones from $S$. mansoni resistant than susceptible individuals [199] and IL-5 correlated with lower levels of S. haematobium infection [99] and S. mansoni reinfection after treatment [200]. Furthermore, IL-4, IL-5, and IL-10 levels were associated with resistance posttreatment while IFN- $\gamma$ was associated with susceptibility [201]. However, significantly higher levels of IFN- $\gamma$ against adult worm and cercariae antigens by PBMCs from resistant individuals compared to those from susceptible individuals [202], suggesting that acquired resistance to human schistosomiasis cannot be exclusively classified into a single $\mathrm{T}$ helper cell subset.

Cellular immune responses, although involved in resistance, mediate most of schistosome-related pathology [203, 204], which can be divided into acute and chronic diseases based on disease progression. Acute schistosomiasis is a debilitating febrile disease which often occurs in individuals with no experience of infection. It is characterized by high percentage of eosinophilia, which may be reversed by chemotherapy [205], nausea, urticaria, dry cough, and fever [206, 207]. Anatomically, this stage is accompanied by a dissemination of large and destructive granulomas around the eggs $[67,208]$. Chronic schistosomiasis is often referred to as a Th2 disease and accounts for most human immunopathologies in endemic areas [77, 204, 208-210]. As infection becomes chronic, schistosome eggs lodge in the liver, gut (S. mansoni), or bladder (S. haematobium), and the granulomatous response translates into extensive tissue damage and excessive extracellular matrix protein (ECMP) deposition, leading to fibrosis [210].

\section{Immunological Interaction between Helminth Antigens and Allergens}

9.1. Helminth Infection and the "Mast Cell Saturation" Hypothesis. The earliest protective mechanism of helminth infection suggested was "mast cell saturation," whereby helminths induce high levels of nonspecific IgE that saturate Fc receptors on mast cells, thus inhibiting hypersensitivity reactions $[211,212]$. Further supportive evidence for the Fc saturation hypothesis came from a study showing that histamine release of human mast cells from lung fragments could be blocked by preexposure of these fragments to high total IgE [213]. However, more recent studies on basophils have shown that high levels of polyclonal $\operatorname{IgE}$ and polyclonal/specific IgE ratios from filarial- and hookworminfected patients do not prevent antigen-induced histamine release $[214,215]$. Nevertheless, Mitre and colleagues were able to show that extremely high ratios of polyclonal/specific $\mathrm{IgE}$, enhanced with polyclonal myeloma IgE in vitro, could prevent histamine release [214]. Although basophils and mast cells may be differentially regulated [216], these experiments suggested that the FceRI receptor saturation may not be the primary mechanism by which helminths "protect" against allergy.

9.2. Helminth Infection and Cross-Reactive IgE Responses. Another hypothesis suggested was that helminth parasites induce a "clinically irrelevant" allergen-specific IgE response, which would be cross-reactive between helminths and allergens [217]. Cross-reactive anti-tropomyosin IgE antibodies between helminths and allergens have recently been demonstrated, where monkeys infected with Loa loa (filarial parasites) mounted an IgE cross-reacting between filarial tropomyosin and Derp 1 allergen but not with timothy grass [218]. Furthermore, cross-reactivity between ascaris and mites has been reported [219]. However, field studies report mixed results on the effects of helminth infections on allergen-specific IgE in endemic areas [220-222]. Our recent study has demonstrated that the levels of anti-Derp1 IgE antibodies inversely correlate with $S$. haematobium infection intensity in a high schistosome infection area in Zimbabwe [223].

9.3. Helminth-Induced Immunomodulation. Technological and scientific advances such as genomic sequences and proteomic approaches have generated molecular and evolutionary information on the relationship between helminth parasites and allergic reactivity. Helminth infections are generally characterised by a Th2-polarised immune response $[25,84,224]$, which is often associated with host resistance to infection/reinfection [30]. However, this Th2 response is also associated with pathology [204], consistent with the role for Th2 in allergic diseases [171]. Nevertheless, helminth parasites are capable of modulating this response to prolong their survival and minimize severe pathology in their host $[76,84,225]$. This immunomodulation is thought to affect unrelated antigens such as allergens, hence dampening the clinical manifestation of allergy. Indeed, experimental studies have demonstrated helminth-induced suppression of allergic responses via multiple pathways (Figure 1). However, these observations and mechanisms remain to be rigorously tested in humans. Furthermore, biological and evolutionary differences in the mouse experimental host and the natural human host must be taken into account when extrapolating 


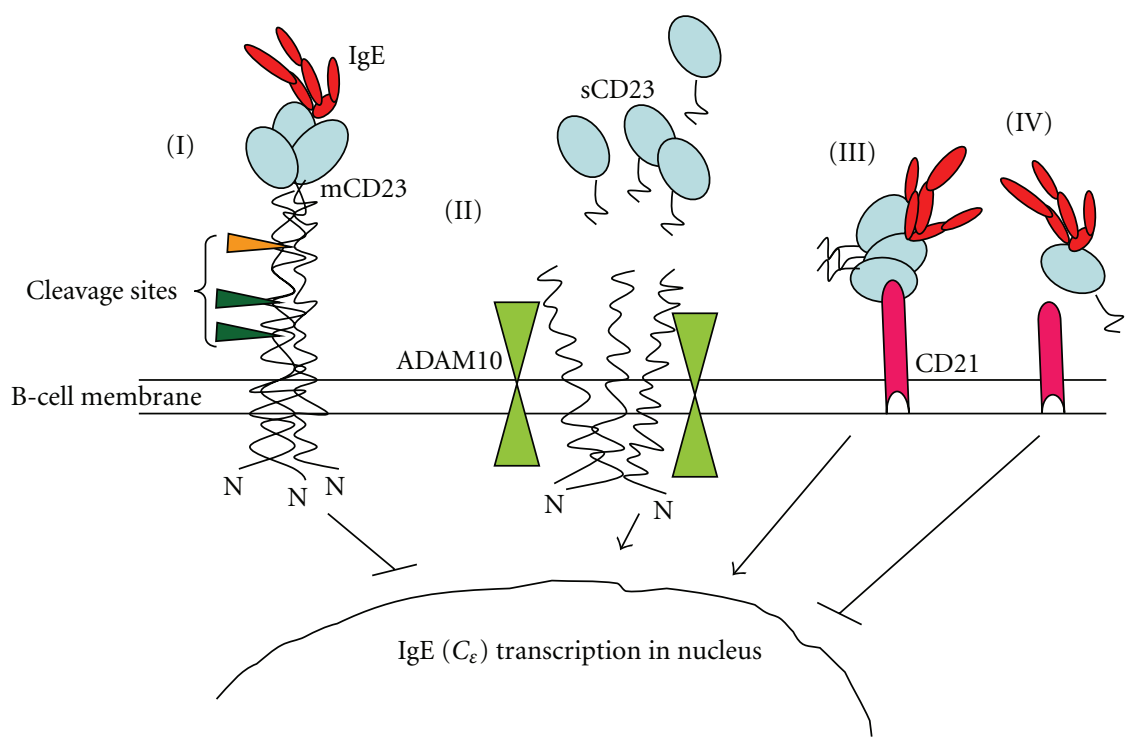

FIgURE 2: Interaction between CD23 and its ligands, IgE and CD21. Binding of IgE stabilises membrane-bound CD23 and inhibits IgE synthesis (I) from activated B cells while in the absence of IgE binding the CD23 is cleaved by ADAM10 (a disintegrin and metalloprotease protein 10) and this destabilisation enhances IgE synthesis (II). However, soluble CD23 (sCD23) fragments resulting from the cleavage have the ability to bind IgE with different affinities depending on their oligomerization state: trimers (III) bind IgE with high affinity while monomers (IV) bind with low affinity. Trimers enhance IgE synthesis by their ability to also bind CD21 receptor (III) while monomers fail to bind CD21 and inhibit IgE synthesis (IV) (adapted from [32-36]).

mechanistic and phenomenological results from the mouse to the human, for example, differences in the IgE receptors [226].

Human studies investigating the regulatory mechanisms underlying the protective effect of helminth infections on atopy have primarily focused on IL-10. Thus, parasiteinduced IL-10 production and skin prick reactivity were negatively associated in Ascaris lumbricoides [42] and Schistosoma haematobium [46] infected populations. Furthermore, allergen-induced IL-10 was associated with reduced Th2 responses (IL-4 and IL-5) in asthmatic schistosome infected patients [227]. More recently, it has been shown that the frequency of PBMCs expressing cytotoxic-T-lymphocyte antigen 4 (CTLA-4) and monocytes expressing IL-10 from asthmatic patients infected with $S$. mansoni was significantly higher compared to their asthmatic uninfected counterparts [228]. However, a study on an Ecuadorian population showed no association between skin prick reactivity with either IL-10 or IL-10-producing T cells induced by Ascaris lumbricoides [40].

The TGF $\beta$ is another cytokine involved in the modulation of immune responses, and is secreted by antigenpresenting cells (APCs) or regulatory T cells [229]. However, there is a paucity of human studies on this cytokine in the context of atopy and helminth infections. Interestingly, we have observed a negative association between atopy and the levels of soluble CD23 in S. haematobium infected populations (Rujeni et al., manuscript in preparation). The CD23 is the low affinity receptor for IgE and is involved in the regulation of these antibodies [35]. As illustrated in Figure 2, the soluble CD23 can either upregulate or downregulate IgE synthesis depending on their size and oligomerization state.
Of note, expression of this receptor has been associated with resistance to schistosome [194] and Ascaris [230] infections in humans, and suppressed airway allergy in helminthinfected mice [231].

As illustrated in Figure 1, immunomodulation during chronic helminth infection is driven by regulatory $\mathrm{T}$ and B cells (Tregs and Bregs, resp.), which secrete the above mentioned anti-inflammatory cytokines. Treg cells are either recruited by Bregs or induced and expanded by helminthderived products [28]. Both $\mathrm{T}$ and $\mathrm{B}$ regulatory cells can suppress Th2 cells thereby regulating atopy and helminthinduced pathology $[31,232]$. Indeed, a study in our lab has shown that Treg proportions correlate with the levels of schistosome infection in young children actively acquiring infection [233].

Helminth molecules have been identified from excretorysecretory (ES) products that are associated with immunomodulation during helminth infection. Thus, the ES-62 is a phosphorylcholine-containing glycoprotein secreted by Acanthocheilonema viteae, a rodent filarial nematode [234]. This protein presents anti-inflammatory properties and has been successfully tested in mouse models of allergy and autoimmune diseases [235, 236], and it is currently being exploited as a potential therapeutic agent for inflammatory diseases in humans [237]. The anti-inflammatory properties of this molecule include modulation of B-cell proliferation and cytokine production as well as hyporesponsiveness and desensitization of mast-cell degranulation [237-240]. The interleukin-4-inducing principle from S. mansoni egg IPSE/alpha-1, identified as one of the most abundant proteins secreted by S. mansoni eggs [241], has also been associated with immunomodulation, possibly by inducing 
granulomatous responses [242]. Furthermore, IPSE/alpha1 has been shown to induce antigen-independent IL-4 production by murine basophils in vivo [243]. The venom allergen-like (VAL) proteins are another group of helminth ES products involved in immunomodulation. Thus, Hewitson et al. have demonstrated that antibodies to these VAL antigens are dominant in susceptible mice in an $H$. polygyrus infection model [244]. Sj-VAL-1 is one of the VAL proteins identified in S. japonicum egg ES products inducing an antibody response during the first 6 weeks of infection in mice [245].

\section{Convergence of Allergic and Antiparasite Responses}

There is current interest in determining the common features in the induction of immune responses by allergens and by helminths as well as the evolutionary advantages of maintaining allergic responses. As illustrated above, several studies have suggested that similarities in antigens may underlie the commonality of Th2 responses elicited by allergens and by helminths. A recent review [246] of allergic responses indicated that there is relatively little structural similarity between different allergens (e.g., house dust mite, food allergens, and haematophagous fluids) and between allergens and helminth parasites. Instead, this paper suggests that the relationship between allergic and antiparasite $\mathrm{Th} 2$ responses arises from a common response to different classes of environmental challenges which include helminth parasites, venoms and haematophagous fluids, and environmental irritants such as carcinogens and noxious xenobiotics, so that this diverse group of stimuli activates responses collectively known as "allergic host defences" [246]. Within this paradigm, these environmental challenges are characterised only by the type of response they elicit with multiple pathways leading to the activation of Th2 responses with the result of protecting against environmental challenges by either reduced exposure to, or elimination of the "irritant." In this scenario, allergic reactivity is believed to have evolved as an important and essential mechanism against harm rather than a harmful overreaction of a misdirected immune system [247]. Studies in cancer patients also show a negative association between cancer and atopy which has led to the suggestion that allergy protects against some types of cancer $[248,249]$. This suggests that the Th2 responses protecting against allergens, carcinogens, and helminths are complex. This presents a challenge for the development of therapeutics relying on helminth products to overcome allergic responses, since induction of allergic responses as well as the effector mechanisms maybe tightly regulated, and the effector responses they elicit may have been selected for redundancy.

\section{Conclusions}

We have shown similarities in the immunological responses to schistosome parasites and to allergens. Studies continue to determine the aetiology of the similar responses and the evolutionary pathways that may have led to the development and maintenance of allergic responses which are paradoxically harmful to the host [246, 247], but may be essential to protect against harm from environmental challenges [246]. The clinical manifestation of atopy is complex with several studies from helminth endemic areas having shown that allergic sensitisation and clinical manifestation of allergy can be dissociated [222]. Furthermore, allergic disease and parasitic infections exist as comorbidities in many patients and are not mutually exclusive [250]. The role of impaired serological allergy diagnosis in parasitized allergy patients as well as under diagnosis in developing countries needs to be addressed to inform future studies. Detailed longitudinal and mechanistic studies relating atopy and clinical disease to schistosome infection and disease in human populations will be valuable to inform on not only the immunological process occurring, but more importantly on clinical management of allergy and schistosomiasis patients.

\section{Acknowledgments}

This paper contains some of our work which was funded by the World Health Organization (Grant no. RPC264), The Welcome Trust (Grant no. WT082028MA), the University of Edinburgh, and the Government of Rwanda. F. Mutapi is funded by the Thrasher Foundation. The authors are grateful to Laura Appleby for providing comments on the manuscript.

\section{References}

[1] N. R. Stoll, “This wormy world," Journal of Parasitology, vol. 33, pp. 1-18, 1947.

[2] GaHI, "Global Atlas of helminth infections," Consulted, Manta Ray Media Ltd, 2012, http://www.thiswormyworld .org/.

[3] P. J. Hotez, J. H. F. Remme, P. Buss, G. Alleyne, C. Morel, and J. G. Breman, "Combating tropical infectious diseases: report of the disease control priorities in developing countries project," Clinical Infectious Diseases, vol. 38, no. 6, pp. 871878, 2004.

[4] P. J. Hotez, P. J. Brindley, J. M. Bethony, C. H. King, E. J. Pearce, and J. Jacobson, "Helminth infections: the great neglected tropical diseases," Journal of Clinical Investigation, vol. 118, no. 4, pp. 1311-1321, 2008.

[5] J. Bethony, S. Brooker, M. Albonico et al., "Soil-transmitted helminth infections: ascariasis, trichuriasis, and hookworm," The Lancet, vol. 367, no. 9521, pp. 1521-1532, 2006.

[6] C. H. King and M. Dangerfield-Cha, "The unacknowledged impact of chronic schistosomiasis," Chronic Illness, vol. 4, no. 1, pp. 65-79, 2008.

[7] C. H. King, K. Dickman, and D. J. Tisch, "Reassessment of the cost of chronic helmintic infection: a meta-analysis of disability-related outcomes in endemic schistosomiasis," The Lancet, vol. 365, no. 9470, pp. 1561-1569, 2005.

[8] N. Aït-Khaled, N. Pearce, H. R. Anderson et al., "Global map of the prevalence of symptoms of rhinoconjunctivitis in children: the International Study of Asthma and Allergies in Childhood (ISAAC) Phase Three," Allergy, vol. 64, no. 1, pp. 123-148, 2009.

[9] H. Williams, C. Robertson, A. Stewart et al., "Worldwide variations in the prevalence of symptoms of atopic eczema in the international study of asthma and allergies in childhood," 
Journal of Allergy and Clinical Immunology, vol. 103, no. 1 I, pp. 125-138, 1999.

[10] E. N. Sibanda, "Inhalant allergies in Zimbabwe: a common problem," International Archives of Allergy and Immunology, vol. 130, no. 1, pp. 2-9, 2003.

[11] R. Beasley, S. Nishima, N. Pearce, and J. Crane, " $\beta$-agonist therapy and asthma mortality in Japan," The Lancet, vol. 351, no. 9113, pp. 1406-1407, 1998.

[12] P. Davis, R. Jackson, and N. Pearce, "Asthma mortality," New Zealand Medical Journal, vol. 98, no. 783, p. 604, 1985.

[13] R. Jackson, "Undertreatment and asthma deaths," The Lancet, vol. 2, no. 8453, p. 500, 1985.

[14] R. Brown, F. Turk, P. Dale, and J. Bousquet, "Cost-effectiveness of omalizumab in patients with severe persistent allergic asthma," Allergy, vol. 62, no. 2, pp. 149-153, 2007.

[15] R. Gupta, A. Sheikh, D. P. Strachan, and H. R. Anderson, "Burden of allergic disease in the UK: secondary analyses of national databases," Clinical and Experimental Allergy, vol. 34, no. 4, pp. 520-526, 2004.

[16] P. Suwan, D. Akaramethathip, and P. Noipayak, "Association between allergic sensitization and attention deficit hyperactivity disorder (ADHD)," Asian Pacific Journal of Allergy and Immunology, vol. 29, no. 1, pp. 57-65, 2011.

[17] M. C. Tsai, H. K. Lin, C. H. Lin, and L. S. Fu, "Prevalence of attention deficit/hyperactivity disorder in pediatric allergic rhinitis: a nationwide population-based study," Allergy and Asthma Proceedings, vol. 32, no. 6, pp. 41-46, 2011.

[18] B. Taylor, J. Wadsworth, M. Wadsworth, and C. Peckham, "Changes in the reported prevalence of childhood eczema since the 1939-45 war," The Lancet, vol. 2, no. 8414, pp. 12551257, 1984.

[19] M. B. Emanuel, "Hay fever, a post industrial revolution epidemic: a history of its growth during the 19th century," Clinical Allergy, vol. 18, no. 3, pp. 295-304, 1988.

[20] F. D. Martinez, D. A. Stem, A. L. Wright, L. M. Taussig, and M. Halonen, "Association of non-wheezing lower respiratory tract illnesses in early life with persistently diminished serum IgE levels," Thorax, vol. 50, no. 10, pp. 1067-1072, 1995.

[21] S. O. Shaheen, P. Aaby, A. J. Hall et al., "Measles and atopy in Guinea-Bissau," The Lancet, vol. 347, no. 9018, pp. 17921796, 1996.

[22] J. S. Alm, G. Lilja, G. Pershagen, and A. Scheynius, "Early BCG vaccination and development of atopy," The Lancet, vol. 350, no. 9075, pp. 400-403, 1997.

[23] I. L. Strannegård, L. O. Larsson, G. Wennergren, and O. Strannegård, "Prevalence of allergy in children in relation to prior BCG vaccination and infection with atypical mycobacteria," Allergy, vol. 53, no. 3, pp. 249-254, 1998.

[24] P. M. Matricardi, F. Rosmini, S. Riondino et al., "Exposure to foodborne and orofecal microbes versus airborne viruses in relation to atopy and allergic asthma: epidemiological study," British Medical Journal, vol. 320, no. 7232, pp. 412-417, 2000.

[25] B. Everts, G. Perona-Wright, H. H. Smits et al., "Omega-1, a glycoprotein secreted by Schistosoma mansoni eggs, drives Th2 responses," Journal of Experimental Medicine, vol. 206, no. 8, pp. 1673-1680, 2009.

[26] M. S. Wilson, M. D. Taylor, M. T. O'Gorman et al., "Helminth-induced CD19+CD23hi B cells modulate experimental allergic and autoimmune inflammation," European Journal of Immunology, vol. 40, no. 6, pp. 1682-1696, 2010.

[27] S. Amu, S. P. Saunders, M. Kronenberg, N. E. Mangan, A. Atzberger, and P. G. Fallon, "Regulatory B cells prevent and reverse allergic airway inflammation via FoxP3-positive $\mathrm{T}$ regulatory cells in a murine model," Journal of Allergy and
Clinical Immunology, vol. 125, no. 5, pp. 1114.e8-1124.e8, 2010.

[28] H. J. McSorley, Y. M. Harcus, J. Murray, M. D. Taylor, and R. M. Maizels, "Expansion of Foxp3 $3^{+}$regulatory T cells in mice infected with the filarial parasite Brugia malayi," Journal of Immunology, vol. 181, no. 9, pp. 6456-6466, 2008.

[29] J. R. Grainger, K. A. Smith, J. P. Hewitson et al., "Helminth secretions induce de novo $\mathrm{T}$ cell Foxp3 expression and regulatory function through the TGF- $\beta$ pathway," Journal of Experimental Medicine, vol. 207, no. 11, pp. 2331-2341, 2010.

[30] J. E. Allen and R. M. Maizels, "Diversity and dialogue in immunity to helminths," Nature Reviews Immunology, vol. 11, no. 6, pp. 375-388, 2011.

[31] L. Hussaarts, L. E. P. M. van der Vlugt, M. Yazdanbakhsh, and H. H. Smits, "Regulatory B-cell induction by helminths: implications for allergic disease," Journal of Allergy and Clinical Immunology, vol. 128, no. 4, pp. 733-739, 2011.

[32] H. J. Gould and B. J. Sutton, "IgE in allergy and asthma today," Nature Reviews Immunology, vol. 8, no. 3, pp. 205217, 2008.

[33] M. Acharya, G. Borland, A. L. Edkins et al., "CD23/FcepsilonRII: molecular multi-tasking," Clinical and Experimental Immunology, vol. 162, no. 1, pp. 12-23, 2010.

[34] R. G. Hibbert, P. Teriete, G. J. Grundy et al., "The structure of human CD23 and its interactions with IgE and CD21," Journal of Experimental Medicine, vol. 202, no. 6, pp. 751760, 2005.

[35] D. H. Conrad, J. W. Ford, J. L. Sturgill, and D. R. Gibb, "CD23: an overlooked regulator of allergic disease," Current Allergy and Asthma Reports, vol. 7, no. 5, pp. 331-337, 2007.

[36] S. L. Bowles, C. Jaeger, C. Ferrara et al., "Comparative binding of soluble fragments (derCD23, sCD23, and exCD23) of recombinant human $\mathrm{CD} 23$ to $\mathrm{CD} 21$ (SCR 1-2) and native IgE, and their effect on IgE regulation," Cellular immunology, vol. 271, no. 2, pp. 371-378, 2011.

[37] D. Dagoye, Z. Bekele, K. Woldemichael et al., "Wheezing, allergy, and parasite infection in children in urban and rural ethiopia," American Journal of Respiratory and Critical Care Medicine, vol. 167, no. 10, pp. 1369-1373, 2003.

[38] N. R. Lynch, I. Hagel, M. Perez, M. C. Di Prisco, R. Lopez, and N. Alvarez, "Effect of anthelmintic treatment on the allergic reactivity of children in a tropical slum," Journal of Allergy and Clinical Immunology, vol. 92, no. 3, pp. 404-411, 1993.

[39] L. J. Palmer, J. C. Celedón, S. T. Weiss, B. Wang, Z. Fang, and $\mathrm{X} . \mathrm{Xu}$, "Ascaris lumbricoides infection is associated with increased risk of childhood asthma and atopy in rural China," American Journal of Respiratory and Critical Care Medicine, vol. 165, no. 11, pp. 1489-1493, 2002.

[40] P. J. Cooper, E. Mitre, A. L. Moncayo, M. E. Chico, M. G. Vaca, and T. B. Nutman, "Ascaris lumbricoides-induced interleukin-10 is not associated with atopy in schoolchildren in a rural area of the tropics," Journal of Infectious Diseases, vol. 197, no. 9, pp. 1333-1340, 2008.

[41] P. J. Cooper, M. E. Chico, M. G. Vaca et al., "Effect of albendazole treatments on the prevalence of atopy in children living in communities endemic for geohelminth parasites: a cluster-randomised trial," The Lancet, vol. 367, no. 9522, pp. 1598-1603, 2006.

[42] C. Flohr, L. N. Tuyen, R. J. Quinnell et al., "Reduced helminth burden increases allergen skin sensitization but not clinical allergy: a randomized, double-blind, placebo-controlled trial in Vietnam," Clinical and Experimental Allergy, vol. 40, no. 1, pp. 131-142, 2010. 
[43] L. C. Rodrigues, P. J. Newcombe, S. S. Cunha et al., "Early infection with Trichuris trichiura and allergen skin test reactivity in later childhood," Clinical and Experimental Allergy, vol. 38, no. 11, pp. 1769-1777, 2008.

[44] M. I. Araujo, A. A. Lopes, M. Medeiros et al., "Inverse association between skin response to aeroallergens and Schistosoma mansoni infection," International Archives of Allergy and Immunology, vol. 123, no. 2, pp. 145-148, 2000.

[45] M. Medeiros Jr., J. P. Figueiredo, M. C. Almeida et al., "Schistosoma mansoni infection is associated with a reduced course of asthma," Journal of Allergy and Clinical Immunology, vol. 111, no. 5, pp. 947-951, 2003.

[46] A. H. J. van den Biggelaar, R. Van Ree, L. C. Rodrigues et al., "Decreased atopy in children infected with Schistosoma haematobium: a role for parasite-induced interleukin-10," The Lancet, vol. 356, no. 9243, pp. 1723-1727, 2000.

[47] P. J. Hotez and A. Fenwick, "Schistosomiasis in Africa: an emerging tragedy in our new global health decade," PLoS Neglected Tropical Diseases, vol. 3, no. 9, article e485, 2009.

[48] A. Fenwick, J. P. Webster, E. Bosque-Oliva et al., "The Schistosomiasis Control Initiative (SCI): rationale, development and implementation from 2002-2008," Parasitology, vol. 136, no. 13, pp. 1719-1730, 2009.

[49] B. Gryseels, K. Polman, J. Clerinx, and L. Kestens, "Human schistosomiasis," The Lancet, vol. 368, no. 9541, pp. 11061118, 2006.

[50] J. R. Stothard and A. F. Gabrielli, "Schistosomiasis in African infants and preschool children: to treat or not to treat?" Trends in Parasitology, vol. 23, no. 3, pp. 83-86, 2007.

[51] J. Ring, "Davos Declaration: allergy as a global problem," Allergy, vol. 67, no. 2, pp. 141-143, 2012.

[52] L. J. Akinbami and K. C. Schoendorf, "Trends in childhood asthma: prevalence, health care utilization, and mortality," Pediatrics, vol. 110, no. 2, part 1, pp. 315-322, 2002.

[53] J. M. Smith, M. E. Disney, J. D. Williams, and Z. A. Goels, "Clinical significance of skin reactions to mite extracts in children with asthma," British Medical Journal, vol. 1, no. 659, pp. 723-726, 1969.

[54] D. O. Miranda, A. O. Deise Silva, F. C. Jorge et al., "Serum and salivary IgE, IgA, and IgG4 antibodies to Dermatophagoides pteronyssinus and its major allergens, Der p1 and Der p2, in allergic and nonallergic children," Clinical and Developmental Immunology, vol. 2011, Article ID 302739, 11 pages, 2011.

[55] J. L. Hopper, M. A. Jenkins, J. B. Carlin, and G. G. Giles, "Increase in the self-reported prevalence of asthma and hay fever in adults over the last generation: a matched parentoffspring study," Australian Journal of Public Health, vol. 19, no. 2, pp. 120-124, 1995.

[56] D. Jarvis, R. Newson, J. Lotvall et al., "Asthma in adults and its association with chronic rhinosinusitis: the GA(2) LEN survey in Europe," Allergy, vol. 67, no. 1, pp. 91-98, 2011.

[57] S. Musafiri, J. van Meerbeeck, L. Musango et al., "Prevalence of atopy, asthma and COPD in an urban and a rural area of an African country," Respiratory Medicine, vol. 105, no. 11, pp. 1596-1605, 2011.

[58] C. K. W. Lai, R. Beasley, J. Crane et al., "Global variation in the prevalence and severity of asthma symptoms: phase Three of the International Study of Asthma and Allergies in Childhood (ISAAC)," Thorax, vol. 64, no. 6, pp. 476-483, 2009.

[59] C. H. Katelaris, B. W. Lee, P. C. Potter et al., "Prevalence and diversity of allergic rhinitis in regions of the world beyond Europe and North America," Clinical and Experimental Allergy, vol. 42, no. 2, pp. 186-207, 2011.
[60] K. Westritschnig, E. Sibanda, W. Thomas et al., "Analysis of the sensitization profile towards allergens in central Africa," Clinical and Experimental Allergy, vol. 33, no. 1, pp. 22-27, 2003.

[61] K. Arkestl, E. Sibanda, C. Thors et al., "Impaired allergy diagnostics among parasite-infected patients caused by IgE antibodies to the carbohydrate epitope galactose- $\alpha 1,3-$ galactose," Journal of Allergy and Clinical Immunology, vol. 127, no. 4, pp. 1024-1028, 2011.

[62] J. C. Samuelson and J. P. Caulfield, "The cercarial glycocalyx of Schistosoma mansoni," Journal of Cell Biology, vol. 100, no. 5, pp. 1423-1434, 1985.

[63] J. T. Culbertson, "The cercaricidal action of normal serums," The Journal of Parasitology, vol. 22, no. 2, 1936.

[64] W. Dias Da Silva and M. D. Kazatchkine, "Schistosoma mansoni: activation of the alternative pathway of human complement by schistosomula," Experimental Parasitology, vol. 50, no. 2, pp. 278-286, 1980.

[65] S. J. Jenkins, J. P. Hewitson, S. Ferret-Bernard, and A. P. Mountford, "Schistosome larvae stimulate macrophage cytokine production through TLR4-dependent and -independent pathways," International Immunology, vol. 17, no. 11, pp. 1409-1418, 2005.

[66] R. A. Paveley, S. A. Aynsley, J. D. Turner et al., “The Mannose Receptor (CD206) is an important pattern recognition receptor (PRR) in the detection of the infective stage of the helminth Schistosoma mansoni and modulates IFNgamma production," International Journal for Parasitology, vol. 41, no. 13-14, pp. 1335-1345, 2011.

[67] J. R. Lambertucci, "Acute Schistosomiasis mansoni: revisited and reconsidered," Memorias do Instituto Oswaldo Cruz, vol. 105, no. 4, pp. 422-435, 2010.

[68] S. V. Brant and E. S. Loker, "Schistosomes in the southwest United States and their potential for causing cercarial dermatitis or swimmer's itch," Journal of Helminthology, vol. 83, no. 2, pp. 191-198, 2009.

[69] S. J. Fraser, S. J. R. Allan, M. Roworth et al., "Cercarial dermatitis in the UK," Clinical and Experimental Dermatology, vol. 34, no. 3, pp. 344-346, 2009.

[70] A. Soleng and R. Mehl, "Geographical distribution of cercarial dermatitis in Norway," Journal of Helminthology, vol. 85, no. 3, pp. 345-352, 2010.

[71] P. C. Cook, S. A. Aynsley, J. D. Turner et al., "Multiple helminth infection of the skin causes lymphocyte hyporesponsiveness mediated by Th2 conditioning of dermal myeloid cells," PLoS Pathogens, vol. 7, no. 3, Article ID e1001323, 2011.

[72] K. Ramaswamy, P. Kumar, and Y. X. He, "A role for parasiteinduced PGE2 in IL-10-mediated host immunoregulation by skin stage schistosomula of Schistosoma mansoni," Journal of Immunology, vol. 165, no. 8, pp. 4567-4574, 2000.

[73] V. Angeli, C. Faveeuw, P. Delerive et al., "Schistosoma mansoni induces the synthesis of IL-6 in pulmonary microvascular endothelial cells: role of IL-6 in the control of lung eosinophilia during infection," European Journal of Immunology, vol. 31, no. 9, pp. 2751-2761, 2001.

[74] F. Trottein, S. Nutten, V. Angeli et al., "Schistosoma mansoni schistosomula reduce E-selectin and VCAM-1 expression in TNF-alpha-stimulated lung microvascular endothelial cells by interfering with the NF-kappaB pathway," European Journal of Immunology, vol. 29, no. 11, pp. 3691-3701, 1999.

[75] E. J. Pearce, C. M. Kane, J. Sun, J. J. Taylor, A. S. McKee, and L. Cervi, "Th2 response polarization during infection with 
die helminth parasite Schistosoma mansoni," Immunological Reviews, vol. 201, pp. 117-126, 2004.

[76] E. J. Pearce and A. S. MacDonald, "The immunobiology of schistosomiasis," Nature Reviews Immunology, vol. 2, no. 7, pp. 499-511, 2002.

[77] H. M. Coutinho, L. P. Acosta, H. W. Wu et al., "Th2 cytokines are associated with persistent hepatic fibrosis in human Schistosoma japonicum infection," Journal of Infectious Diseases, vol. 195, no. 2, pp. 288-295, 2007.

[78] S. Henri, C. Chevillard, A. Mergani et al., "Cytokine regulation of periportal fibrosis in humans infected with Schistosoma mansoni: IFN- $\gamma$ is associated with protection against fibrosis and TNF- $\alpha$ with aggravation of disease," Journal of Immunology, vol. 169, no. 2, pp. 929-936, 2002.

[79] A. Dessein, B. Kouriba, C. Eboumbou et al., "Interleukin-13 in the skin and interferon- $\gamma$ in the liver are key players in immune protection in human schistosomiasis," Immunological Reviews, vol. 201, pp. 180-190, 2004.

[80] P. Smith, R. E. Fallon, N. E. Mangan et al., "Schistosoma mansoni secretes a chemokine binding protein with antiinflammatory activity," Journal of Experimental Medicine, vol. 202, no. 10, pp. 1319-1325, 2005.

[81] L. A. de Oliveira Fraga, E. W. Lamb, E. C. Moreno et al., "Rapid induction of IgE responses to a worm cysteine protease during murine pre-patent schistosome infection," BMC Immunology, vol. 11, article 56, 2010.

[82] M. Nyindo, T. M. Kariuki, P. W. Mola et al., "Role of adult worm antigen-specific immunoglobulin $\mathrm{E}$ in acquired immunity to Schistosoma mansoni infection in baboons," Infection and Immunity, vol. 67, no. 2, pp. 636-642, 1999.

[83] P. Hagan, U. J. Blumenthal, D. Dunn, A. J. G. Simpson, and H. A. Wilkins, "Human IgE, IgG4 and resistance to reinfection with Schistosoma haematobium," Nature, vol. 349, no. 6306, pp. 243-245, 1991.

[84] R. M. Maizels and M. Yazdanbakhsh, "Immune regulation by helminth parasites: cellular and molecular mechanisms," Nature Reviews Immunology, vol. 3, no. 9, pp. 733-744, 2003.

[85] N. E. Mangan, R. E. Fallon, P. Smith, N. Van Rooijen, A. N. McKenzie, and P. G. Fallon, "Helminth infection protects mice from anaphylaxis via IL-10-producing B cells," Journal of Immunology, vol. 173, no. 10, pp. 6346-6356, 2004.

[86] N. E. Mangan, N. Van Rooijen, A. N. J. McKenzie, and P. G. Fallon, "Helminth-modified pulmonary immune response protects mice from allergen-induced airway hyperresponsiveness," Journal of Immunology, vol. 176, no. 1, pp. 138-147, 2006.

[87] R. S. Curwen, P. D. Ashton, D. A. Johnston, and R. A. Wilson, "The Schistosoma mansoni soluble proteome: a comparison across four life-cycle stages," Molecular and Biochemical Parasitology, vol. 138, no. 1, pp. 57-66, 2004.

[88] A. C. Fisher, "A study of the schistosomiasis of the Stanleyville district of the Belgian congo," Transactions of the Royal Society of Tropical Medicine and Hygiene, vol. 28, no. 3, pp. 277-IN1, 1934.

[89] K. S. Warren, "Regulation of the prevalence and intensity of schistosomiasis in man: immunology or ecology?" Journal of Infectious Diseases, vol. 127, no. 5, pp. 595-609, 1973.

[90] A. E. Butterworth, M. Capron, and J. S. Cordingley, "Immunity after treatment of human Schistosomiasis mansoni. II. Identification of resistant individuals, and analysis of their immune responses," Transactions of the Royal Society of Tropical Medicine and Hygiene, vol. 79, no. 3, pp. 393-408, 1985.
[91] D. W. Dunne, A. J. Fulford, A. E. Butterworth, D. Koech, and J. H. Ouma, "Human antibody responses to Schistosoma mansoni: does antigen directed, isotype restriction result in the production of blocking antibodies?" Memorias do Instituto Oswaldo Cruz, vol. 82, supplement 4, pp. 101-104, 1987.

[92] A. E. Butterworth, A. J. Fulford, D. W. Dunne, J. H. Ouma, and R. F. Sturrock, "Longitudinal studies on human schistosomiasis," Philosophical transactions of the Royal Society of London B, vol. 321, no. 1207, pp. 495-511, 1988.

[93] R. M. Anderson and R. M. May, "Herd immunity to helminth infection and implications for parasite control," Nature, vol. 315, no. 6019, pp. 493-496, 1985.

[94] A. J. C. Fulford, A. E. Butterworth, R. F. Sturrock, and J. H. Ouma, "On the use of age-intensity data to detect immunity to parasitic infections, with special reference to Schistosoma mansoni in Kenya," Parasitology, vol. 105, no. 2, pp. 219-227, 1992.

[95] M. E. J. Woolhouse, P. Taylor, D. Matanhire, and S. K. Chandiwana, "Acquired immunity and epidemiology of Schistosoma haematobium," Nature, vol. 351, no. 6329, pp. 757-759, 1991.

[96] K. Marsh and R. W. Snow, "Host-parasite interaction and morbidity in malaria endemic areas," Philosophical Transactions of the Royal Society B, vol. 352, no. 1359, pp. 1385-1394, 1997.

[97] M. E. J. Woolhouse, "Patterns in parasite epidemiology: the peak shift," Parasitology Today, vol. 14, no. 10, pp. 428-434, 1998.

[98] F. Mutapi, P. D. Ndhlovu, P. Hagan, and M. E. J. Woolhouse, "A comparison of humoral responses to Schistosoma haematobium in areas with low and high levels of infection," Parasite Immunology, vol. 19, no. 6, pp. 255-263, 1997.

[99] F. Mutapi, G. Winborn, N. Midzi, M. Taylor, T. Mduluza, and R. M. Maizels, "Cytokine responses to Schistosoma haematobium in a Zimbabwean population: contrasting profiles for IFN- $\gamma$, IL-4, IL-5 and IL-10 with age," BMC Infectious Diseases, vol. 7, article 139, 2007.

[100] C. L. Black, P. N. Mwinzi, E. M. Muok et al., "Influence of exposure history on the immunology and development of resistance to human Schistosomiasis mansoni," PLoS Neglected Tropical Diseases, vol. 4, no. 3, article e637, 2010.

[101] D. M. S. Karanja, A. W. Hightower, D. G. Colley et al., "Resistance to reinfection with Schistosoma mansoni in occupationally exposed adults and effect of HIV-1 co-infection on susceptibility to schistosomiasis: a longitudinal study," The Lancet, vol. 360, no. 9333, pp. 592-596, 2002.

[102] M. Z. Satti, S. M. Sulaiman, M. M. A. Homeida, S. A. Younis, and H. W. Ghalib, "Clinical, parasitological and immunological features of canal cleaners hyper-exposed to Schistosoma mansoni in the Sudan," Clinical and Experimental Immunology, vol. 104, no. 3, pp. 426-431, 1996.

[103] A. J. C. Fulford, M. Webster, J. H. Ouma, G. Kimani, D. W. Dunne, and T. Fulford, "Puberty and age-related changes in susceptibility to schistosome infection," Parasitology Today, vol. 14, no. 1, pp. 23-26, 1998.

[104] S. G. O. Johansson, T. Bieber, R. Dahl et al., "Revised nomenclature for allergy for global use: report of the Nomenclature Review Committee of the World Allergy Organization, October 2003," Journal of Allergy and Clinical Immunology, vol. 113, no. 5, pp. 832-836, 2004.

[105] M. Herr, L. Nikasinovic, C. Foucault et al., "Can early household exposure influence the development of rhinitis symptoms in infancy? Findings from the PARIS birth cohort," 
Annals of Allergy, Asthma and Immunology, vol. 107, no. 4, pp. 303-309, 2011.

[106] S. L. Prescott, "The influence of early environmental exposures on immune development and subsequent risk of allergic disease," Allergy, vol. 66, no. 95, pp. 4-6, 2011.

[107] J. M. Spergel and A. S. Paller, "Atopic dermatitis and the atopic march," Journal of Allergy and Clinical Immunology, vol. 112, no. 6, supplement, pp. S118-S127, 2003.

[108] N. Bhattacharyya, J. Grebner, and N. G. Martinson, "Recurrent acute rhinosinusitis: epidemiology and health care cost burden," Otolaryngology and Head and Neck Surgery. In press.

[109] R. Sporik, S. T. Holgate, and J. J. Cogswell, "Natural history of asthma in childhood-a birth cohort study," Archives of Disease in Childhood, vol. 66, no. 9, pp. 1050-1053, 1991.

[110] M. L. Martinson, J. O. Teitler, and N. E. Reichman, "Health across the life span in the United States and England," American Journal of Epidemiology, vol. 173, no. 8, pp. 858$865,2011$.

[111] C. Y. Hwang, Y. J. Chen, M. W. Lin et al., "Prevalence of atopic dermatitis, allergic rhinitis and asthma in Taiwan: a national study 2000 to 2007," Acta Dermato-Venereologica, vol. 90, no. 6, pp. 589-594, 2010.

[112] E. G. Weinberg, "The atopic march," Current Allergy \& Clinical Immunology, vol. 18, no. 1, pp. 4-5, 2005.

[113] G. Barberio, G. B. Pajno, D. Vita, L. Caminiti, G. W. Canonica, and G. Passalacqua, "Does a "reverse" atopic march exist?" Allergy, vol. 63, no. 12, pp. 1630-1632, 2008.

[114] M. D. Klinnert, H. S. Nelson, M. R. Price, A. D. Adinoff, D. Y. Leung, and D. A. Mrazek, "Onset and persistence of childhood asthma: predictors from infancy," Pediatrics, vol. 108, no. 4, p. E69, 2001.

[115] P. O. Van Asperen, A. S. Kemp, and A. Mukhi, "Atopy in infancy predicts the severity of bronchial hyperresponsiveness in later childhood," Journal of Allergy and Clinical Immunology, vol. 85, no. 4, pp. 790-795, 1990.

[116] P. M. Matricardi, A. Bockelbrink, C. Grüber et al., "Longitudinal trends of total and allergen-specific $\operatorname{IgE}$ throughout childhood," Allergy, vol. 64, no. 7, pp. 1093-1098, 2009.

[117] D. A. Mrazek, M. Klinnert, P. J. Mrazek et al., "Prediction of early-onset asthma in genetically at-risk children," Pediatric Pulmonology, vol. 27, no. 2, pp. 85-94, 1999.

[118] P. G. Holt and D. H. Strickland, "Soothing signals: transplacental transmission of resistance to asthma and allergy," Journal of Experimental Medicine, vol. 206, no. 13, pp. 28612864, 2009.

[119] B. Schaub, J. Liu, S. Höppler et al., "Maternal farm exposure modulates neonatal immune mechanisms through regulatory T cells," Journal of Allergy and Clinical Immunology, vol. 123, no. 4, pp. 774.e5-782.e5, 2009.

[120] J. W. Hollingsworth, S. Maruoka, K. Boon et al., "In utero supplementation with methyl donors enhances allergic airway disease in mice," Journal of Clinical Investigation, vol. 118, no. 10, pp. 3462-3469, 2008.

[121] K. Ishizaka and T. Ishizaka, "Physicochemical properties of reaginic antibody. I. Association of reaginic activity with an immunoglobulin other than $\gamma \mathrm{A}$ - or $\gamma \mathrm{G}$-globulin," Journal of Allergy, vol. 37, no. 3, pp. 169-185, 1966.

[122] K. Ishizaka and T. Ishizaka, "Identification of gammaE-antibodies as a carrier of reaginic activity," Journal of Immunology, vol. 99, no. 6, pp. 1187-1198, 1967.

[123] E. Dehlink, B. Platzer, A. H. Baker et al., "A soluble form of the high affinity IgE receptor, Fc-epsilon-RI, circulates in human serum," PLoS ONE, vol. 6, no. 4, Article ID e19098, 2011.
[124] B. Platzer, E. Dehlink, S. J. Turley, and E. Fiebiger, "How to connect an IgE-driven response with CTL activity?" Cancer Immunol Immunother. In press.

[125] T. Bieber, H. De la Salle, A. Wollenberg et al., "Human epidermal Langerhans cells express the high affinity receptor for immunoglobulin E (FceRI)," Journal of Experimental Medicine, vol. 175, no. 5, pp. 1285-1290, 1992.

[126] A. S. Gounni, B. Lamkhioued, E. Delaporte et al., "The highaffinity IgE receptor on eosinophils: from allergy to parasites or from parasites to allergy?" Journal of Allergy and Clinical Immunology, vol. 94, no. 6, part 2, pp. 1214-1216, 1994.

[127] A. S. Gounni, B. Lamkhioued, K. Ochiai et al., "High-affinity IgE receptor on eosinophils is involved in defence against parasites," Nature, vol. 367, no. 6459, pp. 183-186, 1994.

[128] U. Jeschke, D. Mayr, B. Schiessl et al., "Expression of galectin-1, -3 (gal-1, gal-3) and the thomsen-friedenreich (TF) antigen in normal, IUGR, preeclamptic and HELLP placentas," Placenta, vol. 28, no. 11-12, pp. 1165-1173, 2007.

[129] E. Rindsjö, M. Joerink, N. Papadogiannakis, and A. Scheynius, "IgE in the human placenta: why there?" Allergy, vol. 65, no. 5, pp. 554-560, 2010.

[130] M. Vernersson, M. Aveskogh, and L. Hellman, "Cloning of IgE from the echidna (Tachyglossus aculeatus) and a comparative analysis of $\varepsilon$ chains from all three extant mammalian lineages," Developmental and Comparative Immunology, vol. 28, no. 1, pp. 61-75, 2004.

[131] P. Vieira and K. Rajewsky, "The half-lives of serum immunoglobulins in adult mice," European Journal of Immunology, vol. 18, no. 2, pp. 313-316, 1988.

[132] A. Karnowski, G. Achatz-Straussberger, C. Klockenbusch, G. Achatz, and M. C. Lamers, "Inefficient processing of mRNA for the membrane form of IgE is a genetic mechanism to limit recruitment of IgE-secreting cells," European Journal of Immunology, vol. 36, no. 7, pp. 1917-1925, 2006.

[133] P. Yu, M. Kosco-Vilbois, M. Richards, G. Kohler, and M. C. Lamers, "Negative feedback regulation of IgE synthesis by murine CD23," Nature, vol. 369, no. 6483, pp. 753-756, 1994.

[134] C. Plater-Zyberk and J. Y. Bonnefoy, "Marked amelioration of established collagen-induced arthritis by treatment with antibodies to CD23 in vivo," Nature Medicine, vol. 1, no. 8, pp. 781-785, 1995.

[135] J. C. Byrd, T. J. Kipps, I. W. Flinn et al., "Phase 1/2 study of lumiliximab combined with fludarabine, cyclophosphamide, and rituximab in patients with relapsed or refractory chronic lymphocytic leukemia," Blood, vol. 115, no. 3, pp. 489-495, 2010.

[136] N. Aberle, A. Gagro, S. Rabatić, Z. Reiner-Banovac, and D. Dekaris, "Expression of CD23 antigen and its ligands in children with intrinsic and extrinsic asthma," Allergy, vol. 52, no. 12, pp. 1238-1242, 1997.

[137] J. P. Aubry, S. Pochon, P. Graber, K. U. Jansen, and J. Y. Bonnefoy, "CD21 is a ligand for CD23 and regulates IgE production," Nature, vol. 358, no. 6386, pp. 505-507, 1992.

[138] J. J. Weis, T. F. Tedder, and D. T. Fearon, "Identification of a 145,000 M(r) membrane protein as the C3d receptor (CR2) of human B lymphocytes," Proceedings of the National Academy of Sciences of the United States of America, vol. 81, no. 3, pp. 881-885, 1984.

[139] N. McCloskey, J. Hunt, R. L. Beavil et al., "Soluble CD23 monomers inhibit and oligomers stimulate IGE synthesis in human B cells," Journal of Biological Chemistry, vol. 282, no. 33, pp. 24083-24091, 2007.

[140] F. X. Desvaux, G. Peltre, and B. David, "Characterization of grass pollen-specific IgE, IgA, IgM classes and IgG subclasses 
in allergic patients," International Archives of Allergy and Applied Immunology, vol. 89, no. 2-3, pp. 281-287, 1989.

[141] R. C. Aalberse, S. O. Stapel, J. Schuurman, and T. Rispens, "Immunoglobulin G4: an odd antibody," Clinical and Experimental Allergy, vol. 39, no. 4, pp. 469-477, 2009.

[142] R. C. Aalberse, F. Van Milligen, K. Y. Tan, and S. O. Stapel, "Allergen-specific IgG4 in atopic disease," Allergy, vol. 48, no. 8, pp. 559-569, 1993.

[143] R. Hussain, R. W. Poindexter, and E. A. Ottesen, "Control of allergic reactivity in human filariasis: predominant localization of blocking antibody to the IgG4 subclass," Journal of Immunology, vol. 148, no. 9, pp. 2731-2737, 1992.

[144] P. Rihet, C. E. Demeure, A. J. Dessein, and A. Bourgois, "Strong serum inhibition of specific IgE correlated to competing IgG4, revealed by a new methodology in subjects from a S. mansoni endemic area," European Journal of Immunology, vol. 22, no. 8, pp. 2063-2070, 1992.

[145] F. Mutapi, C. Bourke, Y. Harcus et al., "Differential recognition patterns of Schistosoma haematobium adult worm antigens by the human antibodies $\operatorname{IgA}$, IgE, IgG1 and IgG4," Parasite Immunology, vol. 33, no. 3, pp. 181-192, 2011.

[146] R. C. Aalberse and J. Schuurman, "IgG4 breaking the rules," Immunology, vol. 105, no. 1, pp. 9-19, 2002.

[147] M. V. D. N. Kolfschoten, J. Schuurman, M. Losen et al., "Antiinflammatory activity of human IgG4 antibodies by dynamic Fab arm exchange," Science, vol. 317 , no. 5844, pp. 15541557, 2007.

[148] J. S. van der Zee, P. Van Swieten, and R. C. Aalberse, "Inhibition of complement activation by IgG4 antibodies," Clinical and Experimental Immunology, vol. 64, no. 2, pp. 415-422, 1986.

[149] R. M. Maizels, E. Sartono, A. Kurniawan, F. Partono, M. E. Selkirk, and M. Yazdanbakhsh, "T-cell activation and the balance of antibody isotypes in human lymphatic filariasis," Parasitology Today, vol. 11, no. 2, pp. 50-56, 1995.

[150] T. Adjobimey and A. Hoerauf, "Induction of immunoglobulin G4 in human filariasis: an indicator of immunoregulation," Annals of Tropical Medicine and Parasitology, vol. 104, no. 6, pp. 455-464, 2010.

[151] J. Punnonen, G. Aversa, B. G. Cocks et al., "Interleukin 13 induces interleukin 4-independent IgG4 and IgE synthesis and CD23 expression by human B cells," Proceedings of the National Academy of Sciences of the United States of America, vol. 90, no. 8, pp. 3730-3734, 1993.

[152] T. R. Mosmann, H. Cherwinski, and M. W. Bond, "Two types of murine helper T cell clone. I. Definition according to profiles of lymphokine activities and secreted proteins," Journal of Immunology, vol. 136, no. 7, pp. 2348-2357, 1986.

[153] J. H. Lee, H. H. Yu, L. C. Wang, Y. H. Yang, Y. T. Lin, and B. L. Chiang, "The levels of $\mathrm{CD} 4{ }^{+} \mathrm{CD} 25^{+}$regulatory $\mathrm{T}$ cells in paediatric patients with allergic rhinitis and bronchial asthma," Clinical and Experimental Immunology, vol. 148, no. 1, pp. 53-63, 2007.

[154] S. Dimeloe, A. Nanzer, K. Ryanna, and C. Hawrylowicz, "Regulatory T cells, inflammation and the allergic responsethe role of glucocorticoids and Vitamin D," Journal of Steroid Biochemistry and Molecular Biology, vol. 120, no. 2-3, pp. 8695, 2010.

[155] M. Akdis, "Immune tolerance in allergy," Current Opinion in Immunology, vol. 21, no. 6, pp. 700-707, 2009.

[156] A. Taylor, J. Verhagen, C. A. Akdis, and M. Akdis, "T regulatory cells in allergy and health: a question of allergen specificity and balance," International Archives of Allergy and Immunology, vol. 135, no. 1, pp. 73-82, 2004.
[157] R. M. McLoughlin, A. Calatroni, C. M. Visness et al., "Longitudinal relationship of early life immunomodulatory $\mathrm{T}$ cell phenotype and function to development of allergic sensitization in an urban cohort," Clinical and Experimental Allergy, vol. 42, no. 3, pp. 392-404, 2011.

[158] L. Cosmi, F. Liotta, E. Maggi, S. Romagnani, and F. Annunziato, "Th17 cells: new players in asthma pathogenesis," Allergy, vol. 66, no. 8, pp. 989-998, 2011.

[159] L. Cosmi, L. Maggi, V. Santarlasci et al., "Identification of a novel subset of human circulating memory $\mathrm{CD} 4^{+} \mathrm{T}$ cells that produce both IL-17A and IL-4," Journal of Allergy and Clinical Immunology, vol. 125, no. 1, pp. 222.e4-230.e4, 2010.

[160] P. Jeannin, S. Lecoanet, Y. Delneste, J. F. Gauchat, and J. Y. Bonnefoy, "IgE versus IgG4 production can be differentially regulated by IL-10," Journal of Immunology, vol. 160, no. 7, pp. 3555-3561, 1998.

[161] E. M. Savilahti, V. Rantanen, J. S. Lin et al., "Early recovery from cow's milk allergy is associated with decreasing IgE and increasing IgG4 binding to cow's milk epitopes," Journal of Allergy and Clinical Immunology, vol. 125, no. 6, pp. 1315.e91321.e9, 2010.

[162] M. E. Devey, D. V. Wilson, and A. W. Wheeler, "The IgG subclasses of antibodies of grass pollen allergens produced in hay fever patients during hyposensitization," Clinical Allergy, vol. 6, no. 3, pp. 227-236, 1976.

[163] R. J. Bullock, D. Barnett, and M. E. H. Howden, "Immunologic and clinical responses to parenteral immunotherapy in peanut anaphylaxis-a study using IgE and IgG4 immunoblot monitoring," Allergologia et Immunopathologia, vol. 33, no. 5, pp. 250-256, 2005.

[164] M. T. Gallego, V. Iraola, M. Himly et al., "Depigmented and polymerised house dust mite allergoid: allergen content, induction of IgG4 and clinical response," International Archives of Allergy and Immunology, vol. 153, no. 1, pp. 6169, 2010.

[165] A. Hoerauf, J. Satoguina, M. Saeftel, and S. Specht, "Immunomodulation by filarial nematodes," Parasite Immunology, vol. 27, no. 10-11, pp. 417-429, 2005.

[166] A. Kurniawan, M. Yazdanbakhsh, R. Van Ree et al., "Differential expression of IgE and IgG4 specific antibody responses in asymptomatic and chronic human filariasis," Journal of Immunology, vol. 150, no. 9, pp. 3941-3950, 1993.

[167] Y. Kaneko, F. Nimmerjahn, and J. V. Ravetch, "Antiinflammatory activity of immunoglobulin G resulting from Fc sialylation," Science, vol. 313, no. 5787, pp. 670-673, 2006.

[168] D. N. Mekhaiel, C. T. Daniel-Ribeiro, P. J. Cooper, and R. J. Pleass, "Do regulatory antibodies offer an alternative mechanism to explain the hygiene hypothesis?" Trends in Parasitology, vol. 27, no. 12, pp. 523-529, 2011.

[169] T. H. T. Nguyen and T. B. Casale, "Immune modulation for treatment of allergic disease," Immunological Reviews, vol. 242, no. 1, pp. 258-271, 2011.

[170] A. B. Kay, "T lymphocytes and their products in atopic allergy and asthma," International Archives of Allergy and Applied Immunology, vol. 94, no. 1-4, pp. 189-193, 1991.

[171] M. Jutel and C. A. Akdis, "T-cell subset regulation in atopy," Current Allergy and Asthma Reports, vol. 11, no. 2, pp. 139145, 2011.

[172] W. E. Paul and J. Zhu, "How are T(H)2-type immune responses initiated and amplified?" Nature Reviews Immunology, vol. 10, no. 4, pp. 225-235, 2010.

[173] C. M. Lloyd and E. M. Hessel, "Functions of T cells in asthma: more than just TH2 cells," Nature Reviews Immunology, vol. 10, no. 12, pp. 838-848, 2010. 
[174] L. E. Harrington, R. D. Hatton, P. R. Mangan et al., "Interleukin 17-producing $\mathrm{CD}^{+}$effector $\mathrm{T}$ cells develop via a lineage distinct from the T helper type 1 and 2 lineages," Nature Immunology, vol. 6, no. 11, pp. 1123-1132, 2005.

[175] W. Al-Ramli, D. Préfontaine, F. Chouiali et al., "TH17associated cytokines (IL-17A and IL-17F) in severe asthma," Journal of Allergy and Clinical Immunology, vol. 123, no. 5, pp. 1185-1187, 2009.

[176] M. Veldhoen, C. Uyttenhove, J. van Snick et al., "Transforming growth factor- $\beta$ "reprograms" the differentiation of $\mathrm{T}$ helper 2 cells and promotes an interleukin 9-producing subset," Nature Immunology, vol. 9, no. 12, pp. 1341-1346, 2008.

[177] R. Pawankar, S. Mori, C. Ozu, and S. Kimura, "Overview on the pathomechanisms of allergic rhinitis," Asia Pacific Allergy, vol. 1, no. 3, pp. 157-167, 2011.

[178] A. E. Butterworth, R. F. Sturrock, V. Houba, and P. H. Rees, "Antibody dependent cell mediated damage to schistosomula in vitro," Nature, vol. 252, no. 5483, pp. 503-505, 1974.

[179] P. Hagan, P. J. Moore, and A. B. Adjukiewicz, "In-vitro antibody-dependent killing of schistosomula of Schistosoma haematobium by human eosinophils," Parasite Immunology, vol. 7, no. 6, pp. 617-624, 1985.

[180] A. Capron, J. P. Dessaint, M. Capron, and H. Bazin, "Specific IgE antibodies in immune adherence of normal macrophages to Schistosoma mansoni schistosomules," Nature, vol. 253, no. 5491, pp. 474-475, 1975.

[181] A. Capron and J. P. Dessaint, "IgE: a molecule in search of a function," Annales d'Immunologie, vol. 132, no. 1, pp. 3-8, 1981.

[182] C. Verwaerde, J. M. Grzych, H. Bazin, M. Capron, and A. Capron, "Production of monoclonal anti-Schistosoma mansoni antibodies. Preliminary study of their biological activities," Comptes Rendus des Seances de l"Academie des Sciences D, vol. 289, no. 10, pp. 725-727, 1979.

[183] P. Rihet, C. E. Demeure, A. Bourgois, A. Prata, and A. J. Dessein, "Evidence for an association between human resistance to Schistosoma mansoni and high anti larval IgE levels," European Journal of Immunology, vol. 21, no. 11, pp. 2679-2686, 1991.

[184] D. W. Dunne, A. E. Butterworth, A. J. C. Fulford et al., "Immunity after treatment of human schistosomiasis: association between IgE antibodies to adult worm antigens and resistance to reinfection," European Journal of Immunology, vol. 22, no. 6, pp. 1483-1494, 1992.

[185] I. R. Caldas, R. Correa-Oliveira, E. Colosimo et al., "Susceptibility and resistance to Schistosoma mansoni reinfection: parallel cellular and isotypic immunologic assessment," American Journal of Tropical Medicine and Hygiene, vol. 62, no. 1, pp. 57-64, 2000.

[186] Z. Zhang, H. Wu, S. Chen et al., "Association between IgE antibody against soluble egg antigen and resistance to reinfection with Schistosoma japonicum," Transactions of the Royal Society of Tropical Medicine and Hygiene, vol. 91, no. 5, pp. 606-608, 1997.

[187] M. Jiz, J. F. Friedman, T. Leenstra et al., "Immunoglobulin E (IgE) responses to paramyosin predict resistance to reinfection with Schistosoma japonicum and are attenuated by IgG4," Infection and Immunity, vol. 77, no. 5, pp. 2051-2058, 2009.

[188] C. W. A. Naus, C. J. Van Dam, P. G. Kremsner, F. W. Krijger, and A. M. Decider, "Human IgE, IgG subclass, and IgM responses to worm and egg antigens in Schistosomiasis haematobium: a 12-month study of reinfection in Cameroonian children," Clinical Infectious Diseases, vol. 26, no. 5, pp. 1142-1147, 1998.

[189] A. P. de Moira, A. J. C. Fulford, N. B. Kabatereine, J. H. Ouma, M. Booth, and D. W. Dunne, "Analysis of complex patterns of human exposure and immunity to Schistosomiasis mansoni the influence of age, sex, ethnicity and IgE," PLoS Neglected Tropical Diseases, vol. 4, no. 9, article e820, 2010.

[190] M. Z. Satti, P. Lind, B. J. Vennervald, S. M. Sulaiman, A. A. Daffalla, and H. W. Ghalib, "Specific immunoglobulin measurements related to exposure and resistance to Schistosoma mansoni infection in Sudanese canal cleaners," Clinical and Experimental Immunology, vol. 106, no. 1, pp. 45-54, 1996.

[191] F. Mutapi, T. Mduluza, N. Gomez-Escobar et al., "Immunoepidemiology of human Schistosoma haematobium infection: preferential lgG3 antibody responsiveness to a recombinant antigen dependent on age and parasite burden," BMC Infectious Diseases, vol. 6, article 96, 2006.

[192] F. Mutapi, P. D. Ndhlovu, P. Hagan et al., "Chemotherapy accelerates the development of acquired immune responses to Schistosoma haematobium infection," Journal of Infectious Diseases, vol. 178, no. 1, pp. 289-293, 1998.

[193] J. M. Grzych, D. Grezel, Chuan Bo Xu et al., "IgA antibodies to a protective antigen in human Schistosomiasis mansoni," Journal of Immunology, vol. 150, no. 2, pp. 527-535, 1993.

[194] P. N. M. Mwinzi, L. Ganley-Leal, C. L. Black, W. E. Secor, D. M. S. Karanja, and D. G. Colley, "Circulating $\mathrm{CD} 23^{+}$B cell subset correlates with the development of resistance to Schistosoma mansoni reinfection in occupationally exposed adults who have undergone multiple treatments," Journal of Infectious Diseases, vol. 199, no. 2, pp. 272-279, 2009.

[195] S. R. Smithers and R. J. Terry, "Resistance to experimental infection with Schistosoma mansoni in rhesus monkeys induced by the transfer of adult worms," Transactions of the Royal Society of Tropical Medicine and Hygiene, vol. 61, no. 4, pp. 517-533, 1967.

[196] C. J. Sanderson, A. O’Garra, D. J. Warren, and G. G. B. Klaus, "Eosinophil differentiation factor also has B-cell growth factor activity: proposed name interleukin 4," Proceedings of the National Academy of Sciences of the United States of America, vol. 83, no. 2, pp. 437-440, 1986.

[197] C. J. Sanderson, D. J. Warren, and M. Strath, "Identification of a lymphokine that stimulates eosinophil differentiation in vitro. Its relationship to interleukin 3, and functional properties of eosinophils produced in cultures," Journal of Experimental Medicine, vol. 162, no. 1, pp. 60-74, 1985.

[198] M. Veith, D. W. Taylor, and K. Thorne, "Studies on the enhancement of human eosinophil function by mononuclear cell products in vitro," Clinical and Experimental Immunology, vol. 58, no. 3, pp. 603-610, 1984.

[199] P. Couissinier-Paris and A. J. Dessein, "Schistosoma-specific helper $\mathrm{T}$ cell clones from subjects resistant to infection by Schistosoma mansoni are Th0/2," European Journal of Immunology, vol. 25, no. 8, pp. 2295-2302, 1995.

[200] M. Roberts, A. E. Butterworth, G. Kimani et al., "Immunity after treatment of human schistosomiasis: association between cellular responses and resistance to reinfection," Infection and Immunity, vol. 61, no. 12, pp. 4984-4993, 1993.

[201] T. Mduluza, P. D. Ndhlovu, N. Midzi et al., "Contrasting cellular responses in Schistosoma haematobium infected and exposed individuals from areas of high and low transmission in Zimbabwe," Immunology Letters, vol. 88, no. 3, pp. 249256, 2003. 
[202] I. R. Viana, A. Sher, O. S. Carvalho et al., "Interferon-gamma production by peripheral blood mononuclear cells from residents of an area endemic for Schistosoma mansoni," Transactions of the Royal Society of Tropical Medicine and Hygiene, vol. 88, no. 4, pp. 466-470, 1994.

[203] I. R. Caldas, A. C. Campi-Azevedo, L. F. A. Oliveira, A. M. S. Silveira, R. C. Oliveira, and G. Gazzinelli, "Human Schistosomiasis mansoni: immune responses during acute and chronic phases of the infection," Acta Tropica, vol. 108, no. 23, pp. 109-117, 2008.

[204] C. N. L. De Morais, J. R. De Souza, W. G. Melo et al., "Cytokine profile associated with chronic and acute human Schistosomiasis mansoni," Memorias do Instituto Oswaldo Cruz, vol. 103, no. 6, pp. 561-568, 2008.

[205] G. Gazzinelli, J. R. Lambertucci, and N. Katz, "Immune responses during human Schistosomiasis mansoni. XI. Immunologic status of patients with acute infections and after treatment," Journal of Immunology, vol. 135, no. 3, pp. 2121-2127, 1985.

[206] A. D. Bastos and I. L. Brito, "Acute pulmonary schistosomiasis: HRCT findings and clinical presentation," Jornal Brasileiro de Pneumologia, vol. 37, no. 6, pp. 823-825, 2011.

[207] J. Clerinx, E. Bottieau, D. Wichmann, E. Tannich, and M. Van Esbroeck, "Acute schistosomiasis in a cluster of travelers from Rwanda: diagnostic contribution of schistosome DNA detection in serum compared to parasitology and serology," Journal of Travel Medicine, vol. 18, no. 6, pp. 367-372, 2011.

[208] A. W. Cheever, K. F. Hoffmann, and T. A. Wynn, "Immunopathology of Schistosomiasis mansoni in mice and men," Immunology Today, vol. 21, no. 9, pp. 465-466, 2000.

[209] S. Ikemoto, T. Kishimoto, S. Wada, S. Nishio, and M. Maekawa, "Clinical studies on cell-mediated immunity in patients with urinary bladder carcinoma: blastogenic response, interleukin- 2 production and interferon- $\gamma$ production of lymphocytes," British Journal of Urology, vol. 65, no. 4, pp. 333-338, 1990.

[210] M. S. Wilson, M. M. Mentink-Kane, J. T. Pesce, T. R. Ramalingam, R. Thompson, and T. A. Wynn, "Immunopathology of schistosomiasis," Immunology and Cell Biology, vol. 85, no. 2, pp. 148-154, 2007.

[211] M. Bazaral, H. A. Orgel, and R. N. Hamburger, "The influence of serum IgE levels of selected recipients, including patients with allergy, helminthiasis and tuberculosis, on the apparent $\mathrm{P}-\mathrm{K}$ titre of a reaginic serum," Clinical and Experimental Immunology, vol. 14, no. 1, pp. 117-125, 1973.

[212] I. Hagel, N. R. Lynch, M. Perez, M. C. Di Prisco, R. Lopez, and E. Rojas, "Modulation of the allergic reactivity of slum children by helminthic infection," Parasite Immunology, vol. 15, no. 6, pp. 311-315, 1993.

[213] R. C. Godfrey and C. F. Gradidge, "Allergic sensitisation of human lung fragments prevented by saturation of IgE binding sites," Nature, vol. 259, no. 5543, pp. 484-486, 1976.

[214] E. Mitre, S. Norwood, and T. B. Nutman, "Saturation of immunoglobulin E (IgE) binding sites by polyclonal IgE does not explain the protective effect of helminth infections against atopy," Infection and Immunity, vol. 73, no. 7, pp. 4106-4111, 2005.

[215] D. I. Pritchard, D. S. W. Hooi, A. Brown, M. J. Bockarie, R. Caddick, and R. J. Quinnell, "Basophil competence during hookworm (Necator americanus) infection," American Journal of Tropical Medicine and Hygiene, vol. 77, no. 5, pp. 860865, 2007.

[216] S. J. Galli, "Mast cells and basophils," Current Opinion in Hematology, vol. 7, no. 1, pp. 32-39, 2000.
[217] M. Yazdanbakhsh, P. G. Kremsner, and R. Van Ree, "Immunology: allergy, parasites, and the hygiene hypothesis," Science, vol. 296, no. 5567, pp. 490-494, 2002.

[218] H. C. Santiago, S. Bennuru, A. Boyd, M. Eberhard, and T. B. Nutman, "Structural and immunologic cross-reactivity among filarial and mite tropomyosin: implications for the hygiene hypothesis," Journal of Allergy and Clinical Immunology, vol. 127, no. 2, pp. 479-486, 2011.

[219] L. Caraballo and N. Acevedo, "Allergy in the tropics: the impact of cross-reactivity between mites and ascaris," Frontiers in Bioscience, vol. 3, pp. 51-64, 2011.

[220] N. R. Lynch, I. Hagel, M. Vargas et al., "Effect of age and helminthic infection on IgE levels in slum children," Journal of Investigational Allergology \& Clinical Immunology, vol. 3, no. 2, pp. 96-99, 1993.

[221] N. R. Lynch, M. Palenque, I. Hagel, and M. C. Diprisco, "Clinical improvement of asthma after anthelminthic treatment in a tropical situation," American Journal of Respiratory and Critical Care Medicine, vol. 156, no. 1, pp. 50-54, 1997.

[222] A. M. J. van den Biggelaar, L. C. Rodrigues, R. Van Ree et al., "Long-term treatment of intestinal helminths increases mite skin-test reactivity in Gabonese schoolchildren," Journal of Infectious Diseases, vol. 189, no. 5, pp. 892-900, 2004.

[223] N. Rujeni, N. Nausch, C. D. Bourke et al., "Atopy is inversely related to Schistosome infection intensity: a comparative study in zimbabwean villages with distinct levels of Schistosoma haematobium infection," International Archives of Allergy and Applied Immunology, vol. 158, no. 3, pp. 288-298, 2012.

[224] C. J. Oliphant, J. L. Barlow, and A. N. McKenzie, "Insights into the initiation of type 2 immune responses," Immunology, vol. 134, no. 4, pp. 378-385, 2011.

[225] R. M. Maizels, "Parasite immunomodulation and polymorphisms of the immune system," Journal of Biology, vol. 8, no. 7, article 62, 2009.

[226] H. Kita and G. J. Gleich, "Eosinophils and IgE receptors: a continuing controversy," Blood, vol. 89, no. 10, pp. 34973501, 1997.

[227] M. I. A. S. Araujo, B. Hoppe, M. Medeiros et al., "Impaired $\mathrm{T}$ helper 2 response to aeroallergen in helminth-infected patiente with asthma," Journal of Infectious Diseases, vol. 190, no. 10, pp. 1797-1803, 2004.

[228] R. R. Oliveira, K. J. Gollob, J. P. Figueiredo et al., "Schistosoma mansoni infection alters co-stimulatory molecule expression and cell activation in asthma," Microbes and Infection, vol. 11, no. 2, pp. 223-229, 2009.

[229] R. M. Maizels and M. Yazdanbakhsh, "T-cell regulation in helminth parasite infections: implications for inflammatory diseases," Chemical Immunology and Allergy, vol. 94, pp. 112123, 2008.

[230] I. Hagel, M. Cabrera, P. Sánchez, P. Rodríguez, and J. J. Lattouf, "Role of the low affinity IgE receptor (CD23) on the IgE response against Ascaris lumbricoides in Warao Amerindian children from Venezuela," Investigacion Clinica, vol. 47, no. 3, pp. 241-251, 2006.

[231] M. S. Wilson, M. D. Taylor, A. Balic, C. A. M. Finney, J. R. Lamb, and R. M. Maizels, "Suppression of allergic airway inflammation by helminth-induced regulatory $\mathrm{T}$ cells," Journal of Experimental Medicine, vol. 202, no. 9, pp. 1199-1212, 2005.

[232] Y. Osada and T. Kanazawa, "Parasitic helminths: new weapons against immunological disorders," Journal of Biomedicine \& Biotechnology, vol. 2010, Article ID 743758, p. 9, 2010. 
[233] N. Nausch, N. Midzi, T. Mduluza, R. M. Maizels, and F. Mutapi, "Regulatory and activated $\mathrm{T}$ cells in human Schistosoma haematobium infections," PLoS ONE, vol. 6, no. 2, Article ID e16860, 2011.

[234] W. Harnett and M. M. Harnett, "Helminth-derived immunomodulators: can understanding the worm produce the pill?" Nature Reviews Immunology, vol. 10, no. 4, pp. 278-284, 2010.

[235] A. J. Melendez, M. M. Harnett, P. N. Pushparaj et al., "Inhibition of Fc epsilon RI-mediated mast cell responses by ES-62, a product of parasitic filarial nematodes," Nature Medicine, vol. 13, pp. 1375-1381, 2007.

[236] I. B. McInnes, B. P. Leung, M. Harnett, J. A. Gracie, F. Y. Liew, and W. Harnett, "A novel therapeutic approach targeting articular inflammation using the filarial nematodederived phosphorylcholine-containing glycoprotein ES-62," The Journal of Immunology, vol. 171, no. 4, pp. 2127-2133, 2003.

[237] M. M. Harnett, A. J. Melendez, and W. Harnett, "The therapeutic potential of the filarial nematode-derived immunodulator, ES-62 in inflammatory disease," Clinical \& Experimental Immunology, vol. 159, no. 3, pp. 256-267, 2010.

[238] W. Harnett, M. M. Harnett, B. P. Leung, J. A. Gracie, and I. B. McInnes, "The anti-inflammatory potential of the filarial nematode secreted product, ES-62," Current topics in Medicinal Chemistry, vol. 4, pp. 553-559, 2004.

[239] W. Harnett and M. M. Harnett, "Filarial nematode secreted product ES-62 is an anti-inflammatory agent: therapeutic potential of small molecule derivatives and ES-62 peptide mimetics," Clinical and Experimental Pharmacology \& Physiology, vol. 33, no. 5-6, pp. 511-518, 2006.

[240] M. M. Harnett, D. E. Kean, A. Boitelle et al., "The phosphorycholine moiety of the filarial nematode immunomodulator ES-62 is responsible for its anti-inflammatory action in arthritis," Annals of the Rheumatic Diseases, vol. 67, no. 4, pp. 518-523, 2008.

[241] G. Schramm, F. H. Falcone, A. Gronow et al., "Molecular characterization of an interleukin-4-inducing factor from Schistosoma mansoni eggs," The Journal of Biological Chemistry, vol. 278, no. 20, pp. 18384-818392, 2003.

[242] M.-H. Abdulla, K.-C. Lim, J. H. McKerrow, and C. R. Caffrey, "Proteomic identification of IPSE/alpha-1 as a major hepatotoxin secreted by Schistosoma mansoni eggs," PLoS Neglected Tropical Diseases, vol. 5, no. 10, article e1368, 2011.

[243] G. Schramm, K. Mohrs, M. Wodrich et al., "Cutting edge: IPSE/alpha-1, a glycoprotein from Schistosoma mansoni eggs, induces IgE-dependent, antigen-independent IL-4 production by murine basophils in vivo," The Journal of Immunology, vol. 178, no. 10, pp. 6023-6027, 2007.

[244] J. P. Hewitson, K. J. Filbey, J. R. Grainger et al., "Heligmosomoides polygyrus elicits a dominant nonprotective antibody response directed against restricted glycan and peptide epitopes," The Journal of Immunology, vol. 187, no. 9, pp. 4764-4777, 2011.

[245] J. Chen, X. Hu, S. He et al., "Expression and immune response analysis of Schistosoma japonicum VAL-1, a homologue of vespid venom allergens," Parasitology Research, vol. 106, no. 6, pp. 1413-1418, 2010.

[246] N. W. Palm, R. K. Rosenstein, and R. Medzhitov, "Allergic host defences," Nature, vol. 484, no. 7395, pp. 465-472, 2012.

[247] D. Artis, R. M. Maizels, and F. D. Finkelman, "Forum: immunology: allergy challenged," Nature, vol. 484, no. 7395, pp. 458-459, 2012.
[248] P. W. Sherman, E. Holland, and J. S. Sherman, "Allergies: their role in cancer prevention," Quarterly Review of Biology, vol. 83, no. 4, pp. 339-362, 2008.

[249] B. E. Zacharia and P. Sherman, "Atopy, helminths, and cancer," Medical Hypotheses, vol. 60, no. 1, pp. 1-5, 2003.

[250] E. Sibanda, D. Gallerano, E. Wollmann, and R. Valenta, "EFIS-EJI African International Conference on Immunity (AICI)," European Journal of Immunology, vol. 42, no. 5, pp. 1070-1071, 2012. 

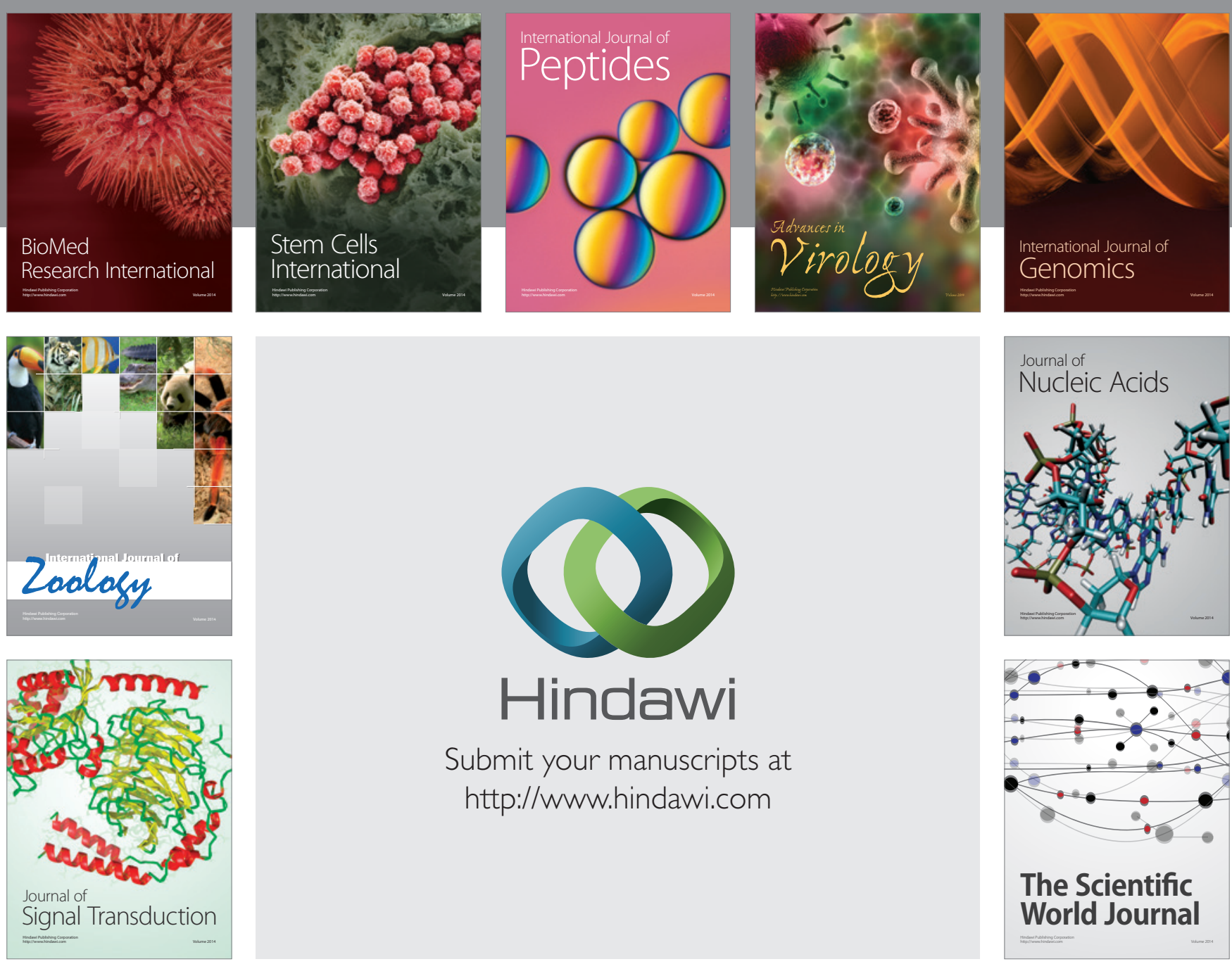

Submit your manuscripts at

http://www.hindawi.com
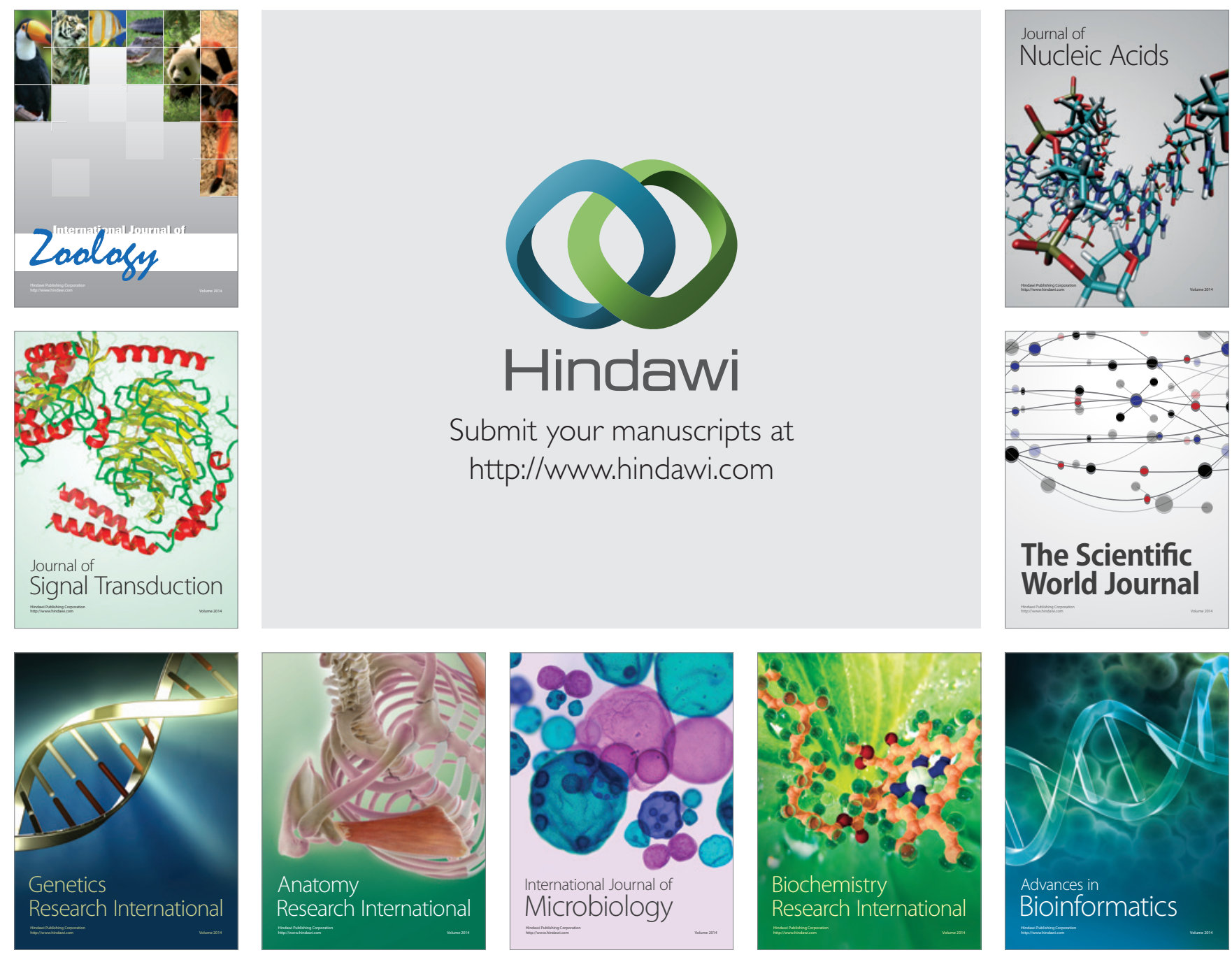

The Scientific World Journal
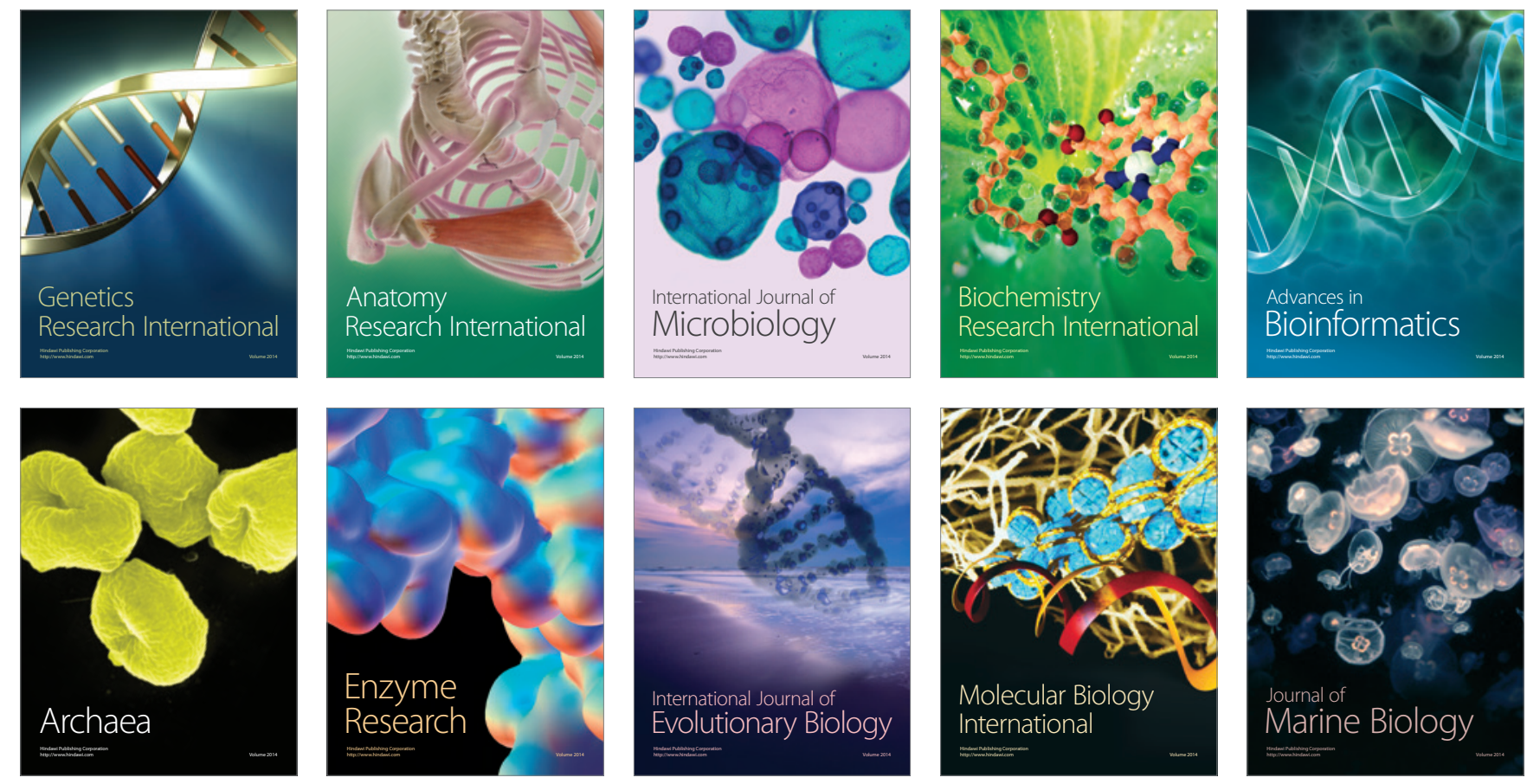